\title{
Article \\ Vascular Polyurethane Prostheses Modified with a Bioactive Coating-Physicochemical, Mechanical and Biological Properties
}

\author{
Aleksandra Kuźmińska *D, Aleksandra Wojciechowska and Beata A. Butruk-Raszeja (D) \\ Biomedical Engineering Laboratory, Faculty of Chemical and Process Engineering, Warsaw University of \\ Technology, Warynskiego 1, 00-645 Warsaw, Poland; aleksandra.wojciechowska2.stud@pw.edu.pl (A.W.); \\ Beata.Raszeja@pw.edu.pl (B.A.B.-R.) \\ * Correspondence: Aleksandra.Kuzminska.dokt@pw.edu.pl; Tel.: +48-22-234-63-27
}

Citation: Kuźmińska, A.; Wojciechowska, A.; Butruk-Raszeja, B.A. Vascular Polyurethane Prostheses Modified with a Bioactive Coating-Physicochemical, Mechanical and Biological Properties. Int. J. Mol. Sci. 2021, 22, 12183. https://doi.org/10.3390/ ijms222212183

Academic Editor: Antonella Piozzi

Received: 15 October 2021

Accepted: 8 November 2021

Published: 10 November 2021

Publisher's Note: MDPI stays neutral with regard to jurisdictional claims in published maps and institutional affiliations.

Copyright: (c) 2021 by the authors. Licensee MDPI, Basel, Switzerland. This article is an open access article distributed under the terms and conditions of the Creative Commons Attribution (CC BY) license (https:// creativecommons.org/licenses/by/ $4.0 /)$.

\begin{abstract}
This study describes a method for the modification of polyurethane small-diameter ( $5 \mathrm{~mm}$ ) vascular prostheses obtained with the phase inversion method. The modification process involves two steps: the introduction of a linker (acrylic acid) and a peptide (REDV and YIGSR). FTIR and XPS analysis confirmed the process of chemical modification. The obtained prostheses had a porosity of approx. $60 \%$, Young's Modulus in the range of 9-11 MPa, and a water contact angle around $40^{\circ}$. Endothelial (EC) and smooth muscle (SMC) cell co-culture showed that the surfaces modified with peptides increase the adhesion of ECs. At the same time, SMCs adhesion was low both on unmodified and peptide-modified surfaces. Analysis of blood-materials interaction showed high hemocompatibility of obtained materials. The whole blood clotting time assay showed differences in the amount of free hemoglobin present in blood contacted with different materials. It can be concluded that the peptide coating increased the hemocompatibility of the surface by increasing ECs adhesion and, at the same time, decreasing platelet adhesion. When comparing both types of peptide coatings, more promising results were obtained for the surfaces coated with the YISGR than REDV-coated prostheses.
\end{abstract}

Keywords: phase-inversion technique; vascular prosthesis; polyurethane; surface modification; hemocompatibility; endothelial cell; REDV; YIGSR

\section{Introduction}

Cardiovascular diseases are still the leading cause of death in the world [1]. Therefore, research is continuously carried out to produce vascular prostheses with small diameters $(<6 \mathrm{~mm})$, especially since autologous transplants are often not possible [2]. However, it is rare for a material to exhibit appropriate physicochemical and mechanical properties and the expected biocompatibility in practice [3]. Therefore, polymers with suitable mechanical and physical parameters are subject to surface modification, which does not change the base material's mechanical properties [4]. The purpose of the modification is to obtain a biocompatible structure or give the surface the desired physiological activity. The type of material surface modification used is closely related to its intended use and period of use [5]. Bioactive coatings are characterized by the lack of toxicity and no negative reaction of the body in long-term contact with living tissue and body fluids [6]. These materials, due to biochemical reactions, interact with the surrounding environment [7]. They can activate a cascade of biological events that ultimately contribute to regeneration or allow tissue replacement while maintaining their full functionality [8]. The modified material's necessary properties are biocompatibility, no allergic or toxic reactions, adequate mechanical strength, the ability for cells adhesion, and a lack or reduction of blood coagulation $[9,10]$. The prevention of blood clots and the maintenance of the body's hemostasis becomes crucial [11]. This is especially important in small diameter vascular prostheses, 
where the clot can lead to the closure of the scaffold's lumen [12]. The most commonly used polymers for vascular prostheses production are polyurethanes $[13,14]$, known to have a high level of hemocompatibility [15]. Yet, it may be destructive to platelets. Therefore, surface modification represents an important issue.

One of the methods of surface modification is the chemical introduction of functional groups. Such groups (e.g., carboxyl) can be further reacted, thanks to which bioactive particles can be introduced onto the surfaces [16]. For example, acrylic acid can be used as a linker $[17,18]$. Biomimetic materials are able to cause specific cellular responses $[16,19]$. For endothelialization, ECM-derived short peptide sequences that selectively promote the adhesion and proliferation of endothelial cells are most promising [20,21]. Tetrapeptide REDV is a fibronectin-derived peptide, known for its adhesive properties. It allows endothelial cells (ECs) attachment and proliferation, but limits the adhesion of vascular smooth muscle [22,23]. YIGSR is not as selective as REDV; it also promotes adhesion of both ECs and smooth muscle cells [24]. Both peptide sequences inhibit platelet adhesion [25,26].

Phase inversion is not the most common technique in the literature for the production of vascular prostheses. However, with this method, after selecting the optimal process parameters, it is possible to create a structure with an appropriate morphology and mechanical properties [27-29].

The study aimed to obtain a tissue scaffold to use as a vascular prosthesis using the phase inversion method. In previous studies, the manufacturing parameters were selected to receive the material with the desired surface morphology [30]. The next step described here was surface modification with a previously developed method [31,32], albeit with the process parameters adjusted for the material produced by the phase inversion. Such modification increases surface wettability, resulting in better cell adhesion. In the case of the modification of flat structures, an increase in bio- and hemocompatibility has been proven Previous works have focused on modifying other forms of materials prepared by varied techniques (foil via solvent casting, fibers via solution blow spinning) from different types of polyurethane, with a different geometry (flat discs) and surface morphology. Moreover, the reaction was carried out with different process parameters (higher concentrations of reagents, different temperatures). This work focuses on the possibility of modifying the cylindrical structure produced by a method not studied before, namely the phase inversion technique. It is worth emphasizing that prostheses obtained by this method have completely different properties than the polyurethane solid discs or fibers. Moreover, the influence of the modification on both surface morphology and mechanical properties was investigated. The study aimed to examine the effect of surface modifications on the biological properties of the produced material. The selectivity of the REDV and YIGSR sequences on the cells of endothelial and muscle cells was investigated. The introduction of the peptide sequences on the interaction of the material with blood was also assessed with platelet adhesion and whole blot clotting time assays.

\section{Results}

\subsection{Surface Morphology}

The studies focused on the internal surface, which will have constant contact with cells and blood, assuming the use as a vascular prosthesis. Figure 1 presents a macroscopic image of the manufactured structure and representative SEM photographs of the obtained materials' internal surface. All materials had inner surfaces which were homogeneously porous with spherical pores. The pores were round and similar in shape, and the surface was smooth with single artifacts. The modification did not influence the prosthesis' wall thickness; for all materials, it was approximately $230 \mu \mathrm{m}$, with no statistical difference between tested materials' variants. 

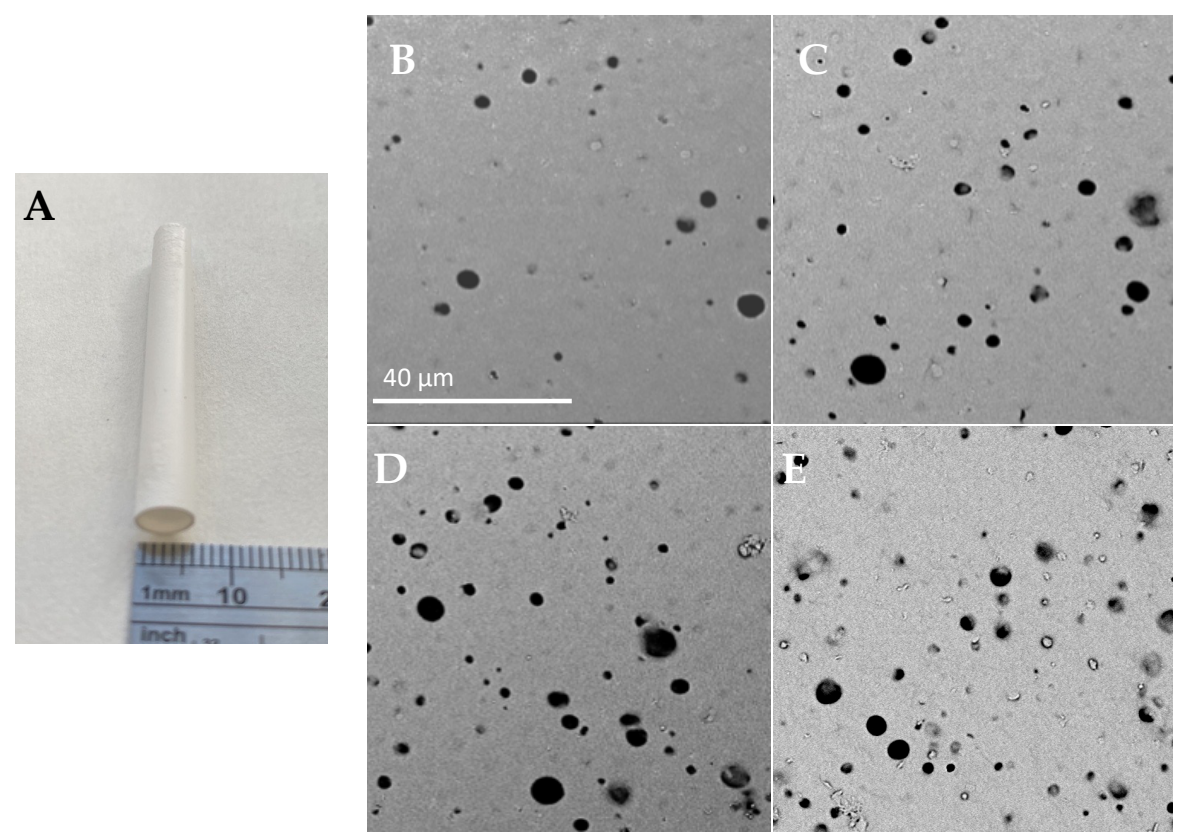

Figure 1. (A) Macroscopic images of prosthesis'; Morphology of prosthesis' internal surface, (B): PU, (C): PU_AA, (D): PU_REDV, (E): PU_YIGSR; scale bar: $40 \mu \mathrm{m}$.

The modification process extended the range of surface pore sizes (Figure 2). The average surface pores size has significantly increased $(p<0.05)$ (Table 1) -from $3.0 \pm 1.0 \mu \mathrm{m}$ for unmodified PU to $4.4 \pm 1.5$ and $4.6 \pm 1.9$ for PU_REDV and PU_YIGSR. Similarly, an increase in maximum (from $5.8 \mu \mathrm{m}$ for PU to $9.5 / 10.1 \mu \mathrm{m}$ for PU_REDV/PU_YIGSR) and minimal (from $1 \mu \mathrm{m}$ for PU to 1.4/1.6 $\mu \mathrm{m}$ for PU_REDV/PU_YIGSR) size was observed.

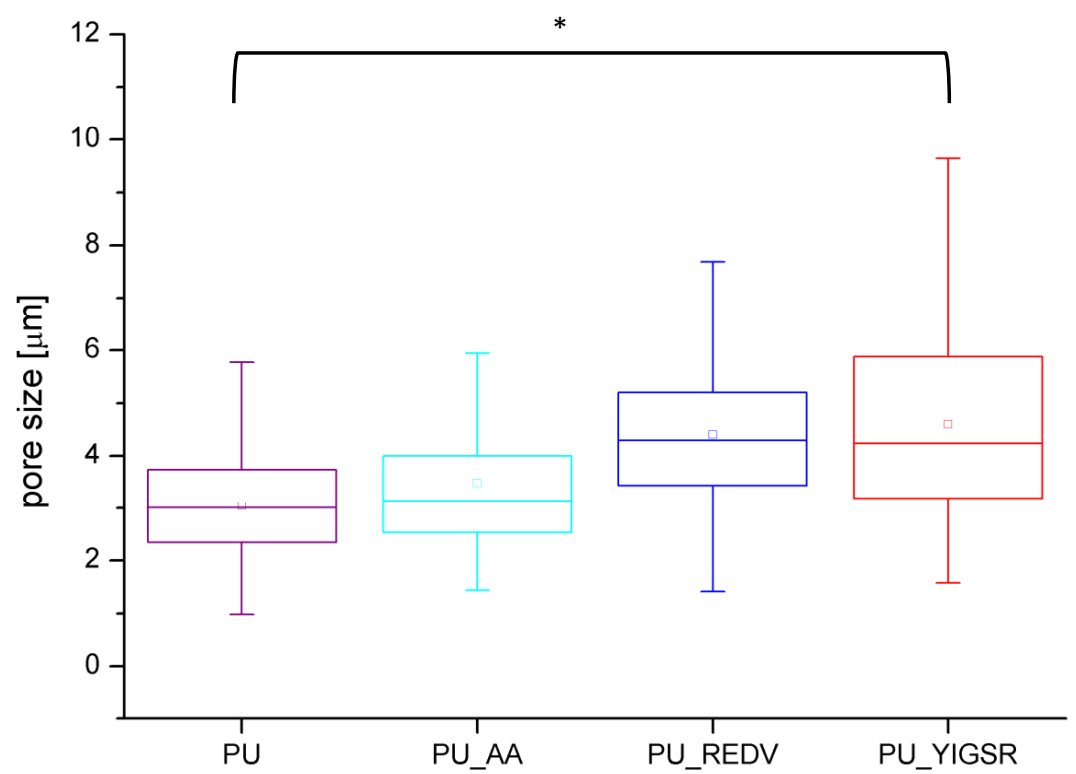

Figure 2. Pore size distribution for obtained materials $(\mathrm{n}=100),{ }^{*}: p<0.05$. 
Table 1. Psychical and mechanical properties of obtained materials (MV $\pm S D$ ).

\begin{tabular}{|c|c|c|c|c|}
\hline Material & PU & PU_AA & PU_REDV & PU_YIGSR \\
\hline wall thickness $[\mu \mathrm{m}]$ & $230.8 \pm 41.5$ & $228.6 \pm 35.4$ & $227.1 \pm 34.0$ & $229.9 \pm 33.2$ \\
\hline $\begin{array}{c}\text { average surface pore } \\
\text { diameter }[\mu \mathrm{m}]\end{array}$ & $3.0 \pm 1.0$ & $\begin{array}{c}* \\
3.5 \pm 1.4\end{array}$ & $\begin{array}{c}* \\
4.4 \pm 1.5\end{array}$ & $\begin{array}{c}* \\
* \\
4.6 \pm 1.9\end{array}$ \\
\hline $\begin{array}{c}\text { min surface pore } \\
\text { diameter }[\mu \mathrm{m}]\end{array}$ & 1.0 & 1.4 & 1.4 & 1.6 \\
\hline $\begin{array}{c}\text { max surface pore } \\
\text { diameter }[\mu \mathrm{m}]\end{array}$ & 5.8 & 9.0 & 9.5 & 10.1 \\
\hline porosity [\%] & $56 \pm 2$ & $\begin{array}{c}* \\
65 \pm 5 \\
\end{array}$ & $\begin{array}{c}* \\
62 \pm 6 \\
\end{array}$ & $\begin{array}{c}* \\
63 \pm 3\end{array}$ \\
\hline Young's modulus [MPa] & $3.6 \pm 1.5$ & $\begin{array}{c}* \\
9.1 \pm 1.7 \\
\end{array}$ & $\begin{array}{c}* \\
9.8 \pm 1.8 \\
\end{array}$ & 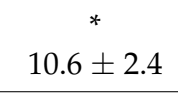 \\
\hline tensile strength [MPa] & $11.2 \pm 1.2$ & $\begin{array}{c}* \\
3.8 \pm 1.1 \\
\end{array}$ & $\begin{array}{c}* \\
* \\
5.7 \pm 0.7\end{array}$ & $\begin{array}{c}* \\
6.7 \pm 1.1\end{array}$ \\
\hline $\begin{array}{c}\text { elongation at break } \\
{[\mathrm{mm} / \mathrm{mm}]}\end{array}$ & $4.7 \pm 0.4$ & $\begin{array}{c}* \\
1.4 \pm 0.5\end{array}$ & $\begin{array}{c}* \\
* \\
1.9 \pm 0.3\end{array}$ & $\begin{array}{c}* \\
2.1 \pm 0.4\end{array}$ \\
\hline
\end{tabular}

\subsection{Porosity}

In Table 1, the basic properties of obtained materials are presented, including porosity results. The modification process increased the prostheses' porosity by approximately 13 percentage points, from $56 \pm 2 \%$ for PU to $62 \pm 6 \% / 63 \pm 3 \%$ for PU_REDV/PU_YIGSR. The difference was statistically significant $(p<0.05)$. This is related to an increase in the size of surface pores. No statistically significant differences in porosity between PU_AA, PU_REDV, PU_YIGSR variants were observed.

\subsection{Mechanical Testing}

Table 1 presents the mechanical properties of analyzed materials. Unmodified PU shows the lowest Young's modulus (YM). The modification process increased YM values. Differences between modified variants were not statistically significant $(p>0.05)$. An inverse relationship was observed for tensile strength and elongation at the break-values statistically significantly decreased $(p>0.05)$. In the case of PU_AA, both of these parameters had the lowest values. Values for peptide-modified materials didn't differ statistically significantly between themselves.

\subsection{Chemical Characterization}

The modification process was monitored by FTIR analysis (Figure 3). The occurrence of surface modification is confirmed by changes in the $\sim 3600-3000 \mathrm{~cm}^{-1}$ region of the spectrum. In the PU_AA is a visible higher peak at $\sim 3300 \mathrm{~cm}^{-1}$. For PU_REDV and PU_YIGSR peak at $\sim 3300 \mathrm{~cm}^{-1}$ is higher than for PU_AA. Moreover, at $3700-3400 \mathrm{~cm}^{-1}$, stretching vibration bands referring to $\mathrm{NH}_{2},-\mathrm{OH}$, and $-\mathrm{C}=\mathrm{O}$ groups are visible $[33,34]$.

XPS analysis enabled monitoring of the subsequent steps of the modification reaction. XPS spectra of C1s and O1s are presented in Figure 4. In the case of the unmodified PU, the $\mathrm{C} 1 \mathrm{~s}$ spectrum can be curve-fitted into five peaks. The four peaks with BEs of about 284.29, $285.88,286.38$, and $288.73 \mathrm{eV}$ are attributable to the $\mathrm{C}-\mathrm{H}, \mathrm{C}-\mathrm{N}, \mathrm{C}-\mathrm{O}$, and $\mathrm{O}-(\mathrm{C}=\mathrm{O})-\mathrm{N}$ species, which is following data presented for polyurethanes [35]. The fifth peak with a high $\mathrm{BE}$ of $289.9 \mathrm{eV}$ corresponds to the carbonate group $(\mathrm{O}-(\mathrm{C}=\mathrm{O})-\mathrm{O})$ [36] of ChronoFlex, which is a carbonate-based polyurethane. After conjugation with peptide, both in case of PU_REDV and PU_YIGSR, peak with BEs of about $288 \mathrm{eV}$ slightly increases with can be associated with the introduction of amide group [37]. Greater changes are visible in the O1s spectrum O1s. The spectrum for PU was separated into two components corresponding to 
the binding energy $\sim 531 \mathrm{eV}$ (double-bonded oxygen) and $\sim 533 \mathrm{eV}$ (single-bonded oxygen). In the case of PU_REDV/PU_YIGSR, two peaks also appeared. However, the intensity of peaks corresponded with double-bonded oxygen strongly increased.

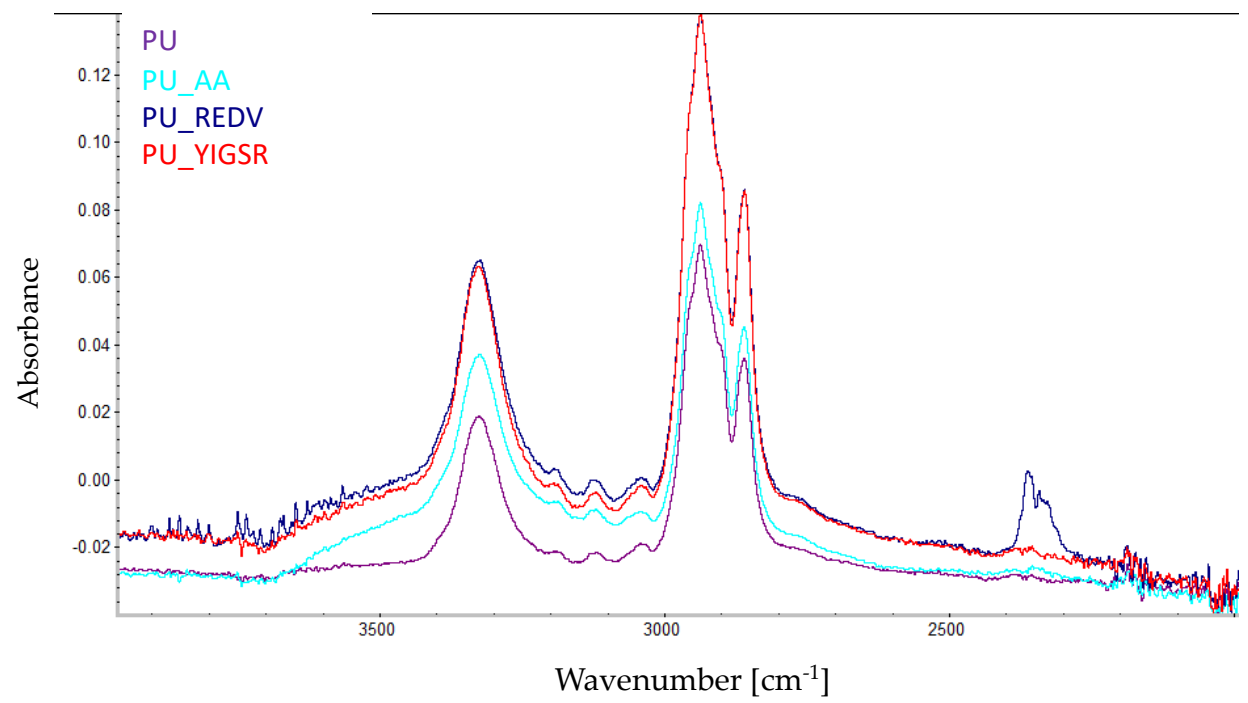

Figure 3. FTIR spectra recorded for the modified surfaces after each modification step.

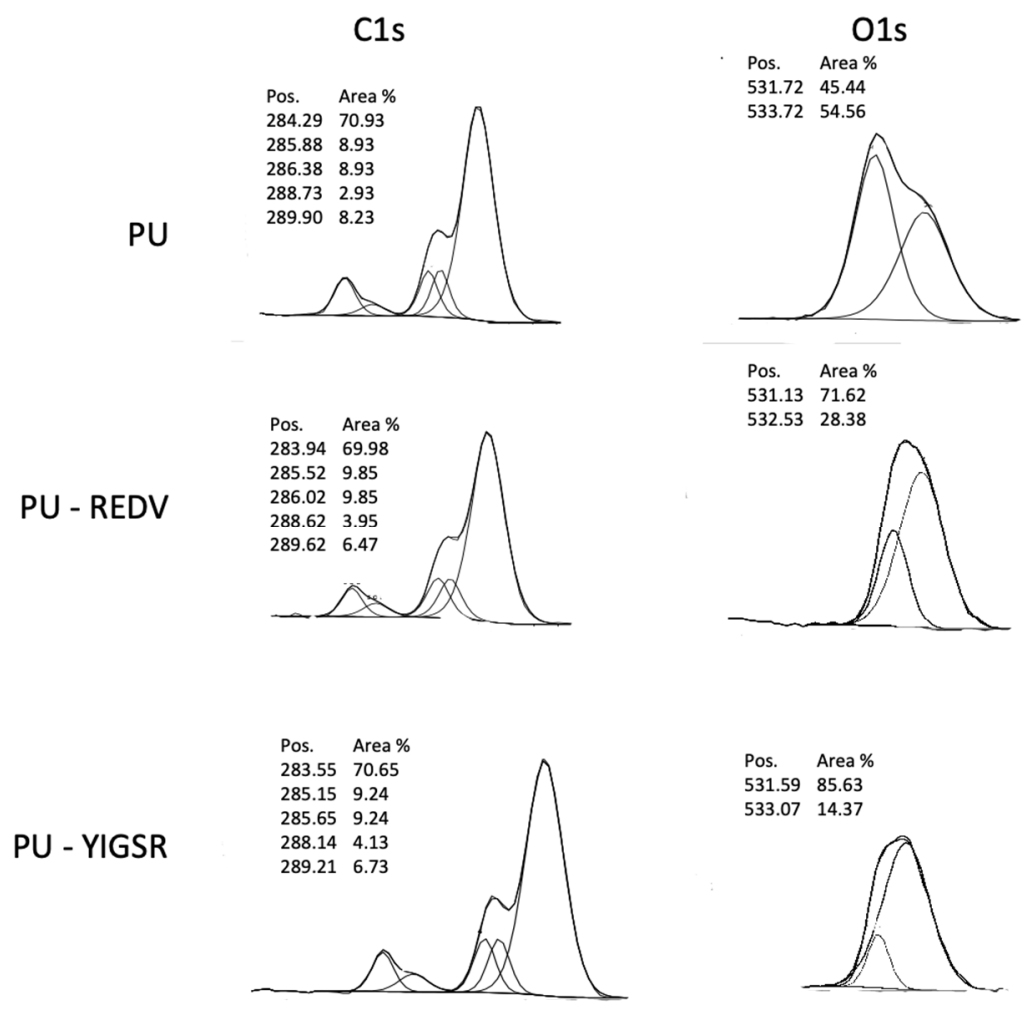

Figure 4. X-ray photoelectron spectroscopy (XPS) spectra of carbon C1s and O1s.

\subsection{Water Contact Angle}

The results of surface wettability measurements are presented in Figure 5. The unmodified PU has WCA $=79.7 \pm 3.0^{\circ}$, which means it is slightly hydrophilic. After modification, the wettability of the surface increased. WCA values for all modified surfaces statistically significantly differed $(p<0.05)$ from the unmodified PU WCA value. The reduction of WCA confirms that both steps of the modifying process have taken place successfully. 
After the modification's first step (the AA introduction), WCA value was reduced to $65.1 \pm 5.3^{\circ}$. The conjugation with peptides resulted in further reduction of WCA values (PU_REDV: $43.9 \pm 8.8^{\circ}$, PU_YIGSR: $43.4 \pm 7.3^{\circ}$, respectively (statistically significant differed $(p<0.05))$ ).

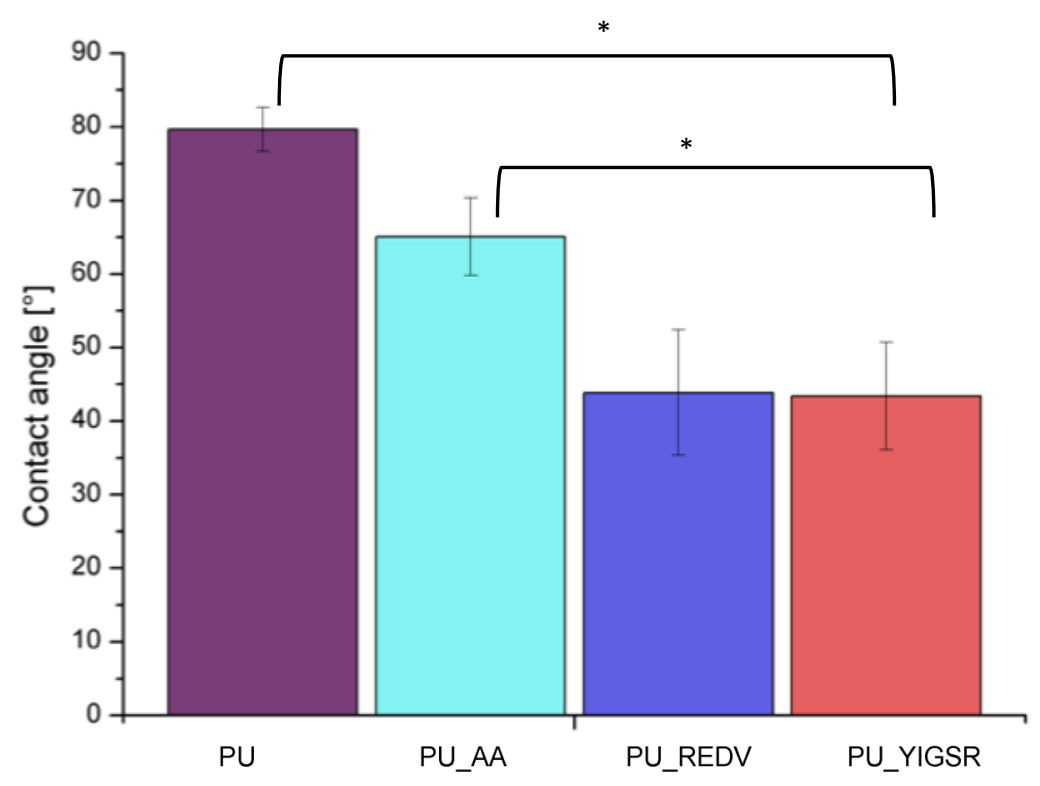

Figure 5. The wettability results (MV $\pm \mathrm{SD}, \mathrm{n}=4){ }^{*}: p<0.05$.

\subsection{COOH Group Determination}

The TBO assay confirms the introduction of carboxyl groups to the surface by the proposed modification method (Figure 6). The unmodified PU gave a slight response in the TBO test $\left(8.5 \pm 0.8 \mathrm{nmol} / \mathrm{cm}^{2}\right)$. This is due to the fact that the materials' structure is porous, and the dye has physically deposited on the material. After the first step, the AA introduction, the number of $\mathrm{COOH}$ groups increases significantly to $37.5 \pm 4.7$ $\mathrm{nmol} / \mathrm{cm}^{2}(p<0.05)$. After the next step, the reaction with the peptides, the number of groups decreased significantly $(p<0.05)$ compared to PU_AA. Which is an expected result as $\mathrm{COOH}$ groups were involved in the reaction with the peptide sequences. There is no statistically significant difference between PU_REDV and PU_YIGSR $\left(24.4 \pm 2.1 \mathrm{nmol} / \mathrm{cm}^{2}\right.$ and $25.9 \pm 1.4 \mathrm{nmol} / \mathrm{cm}^{2}$, respectively). 


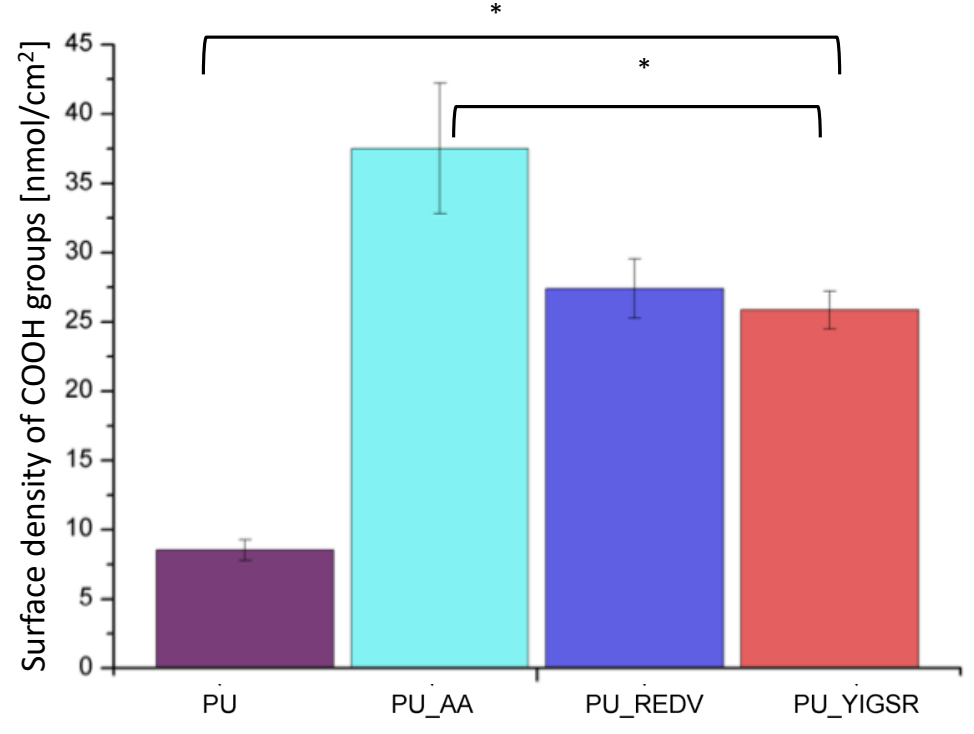

Figure 6. Results of $\mathrm{TBO}$ assay $(\mathrm{MV} \pm \mathrm{SD}, \mathrm{n}=4){ }^{*}: p<0.05$.

\subsection{Cytotoxicity}

MTT assay (Figure 7) showed that the viability of cells contacted with all analyzed extracts was close to the control value and significantly exceeded 70\%. According to ISO 10993-5 norm, cell viability higher than 70\% characterizes non-toxic materials, so it can be concluded that all tested surfaces are biocompatible.

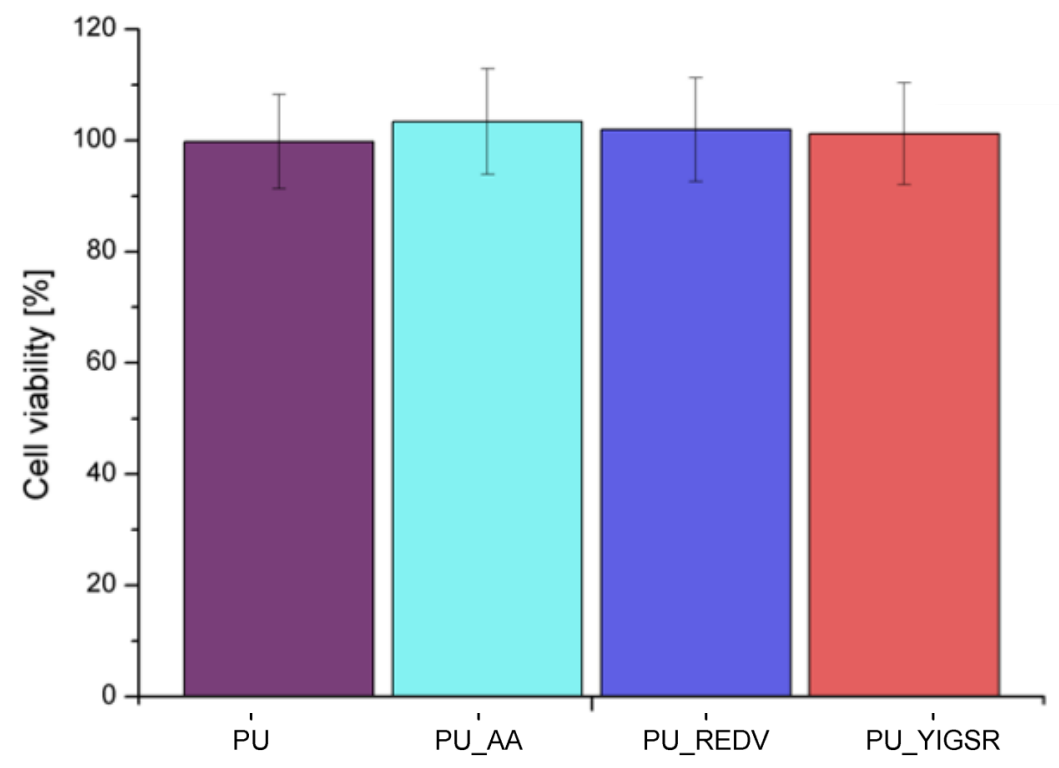

Figure 7. Cell viability (MV $\pm S D, n=4)$.

\subsection{Endothelial and Smooth Muscle Cell Co-Culture}

EC and SMC co-culture was performed on internal surfaces of the unmodified PU, PU_REDV, and PU_YIGSR for one and three days (Figure 8, Table 2). 
Table 2. Percent of the area occupied by EC and SMC.

\begin{tabular}{ccccc}
\hline & & PU & PU_REDV & PU_YIGSR \\
\hline \multirow{2}{*}{ Area coated with ECs [\%] } & 1 day & $<1$ & $4 \pm 2$ & $11 \pm 8^{*, \#}$ \\
\cline { 2 - 5 } & 3 day & $8 \pm 6$ & $10 \pm 7$ & $12 \pm 3$ \\
\hline \multirow{2}{*}{ Area coated with SMCs [\%] } & 1 day & $<1$ & $<1$ & $<1$ \\
\cline { 2 - 5 } & 3 day & $<1$ & $2 \pm 2$ & $3 \pm 3$ \\
\hline$p<0.05$ vs. PU, $\#<0.05$ vs. PU REDV. & & &
\end{tabular}

\section{$24 \mathrm{~h}$}

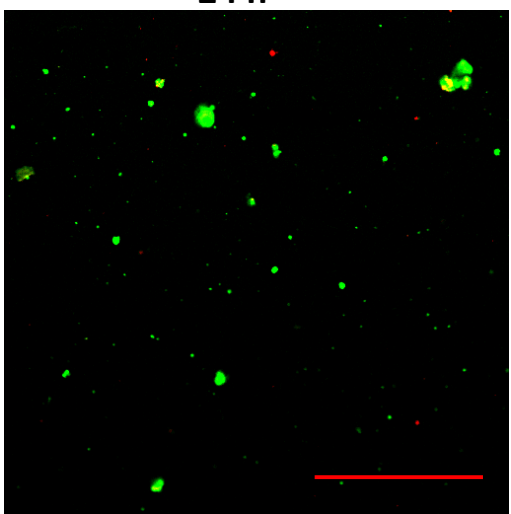

PU
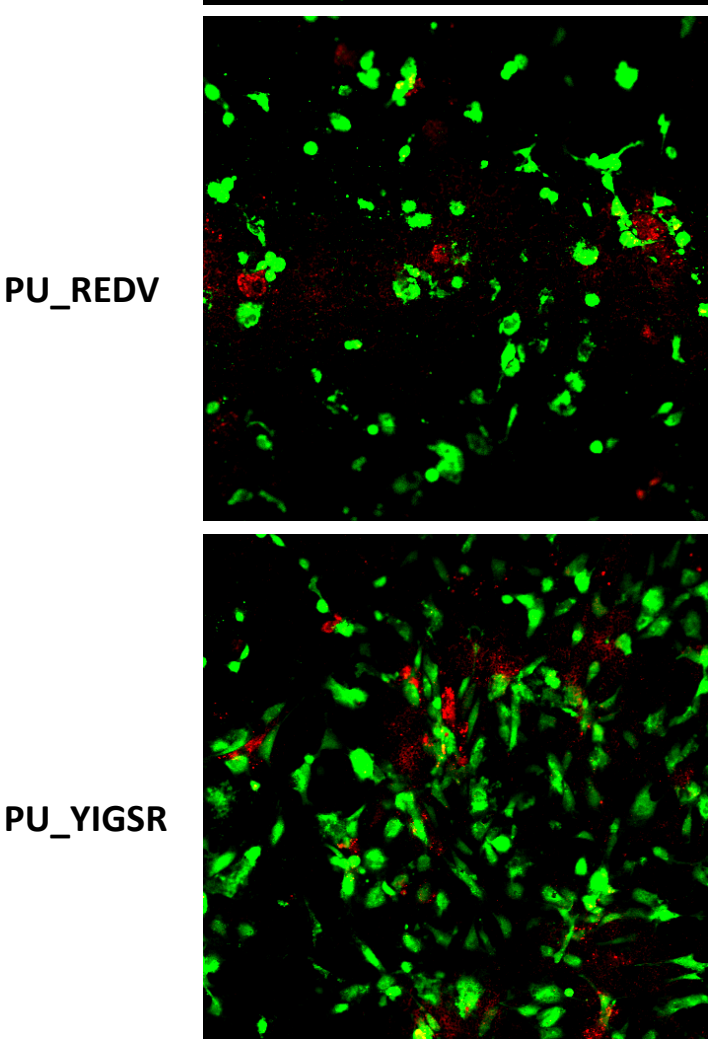

$72 \mathrm{~h}$
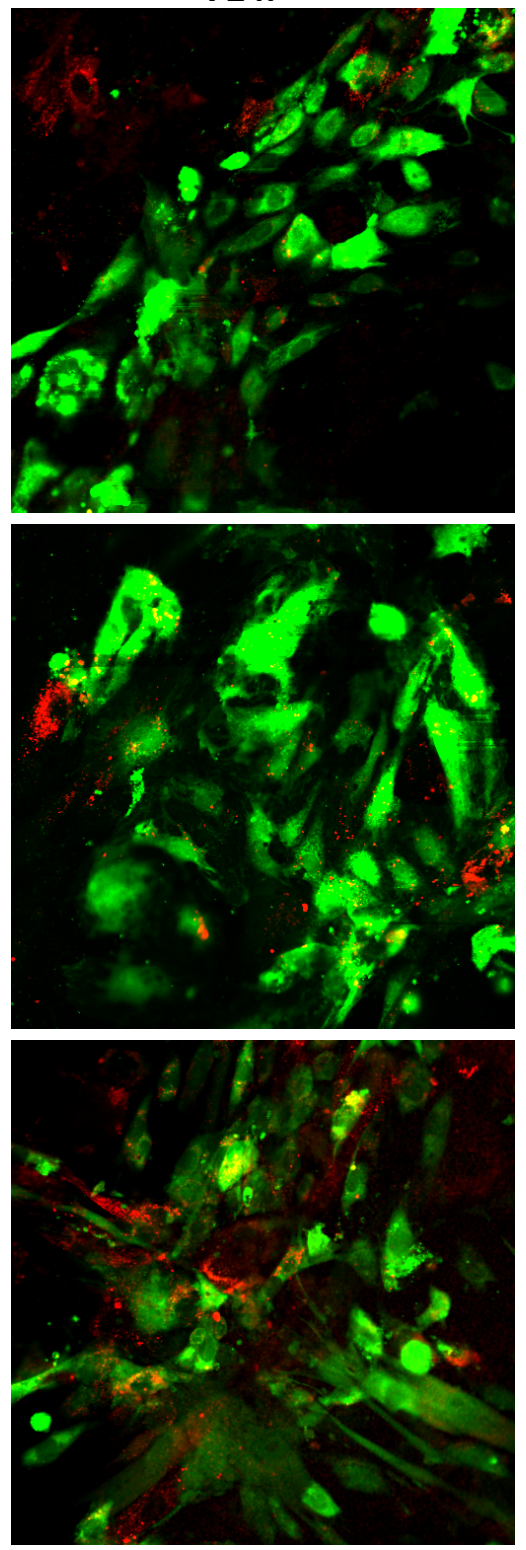

Figure 8. Endothelial cells (green) and smooth muscle cells (red) co-cultured on tested materials, scale bar $100 \mu \mathrm{m}$.

After $24 \mathrm{~h}$ of culture, single spherical cells were observed on the surface of the pristine PU. Most of them were ECs, only a few SMCs were found. The percentage of the cell-coated area was below $1 \%$. In the case of PU_REDV, a significantly bigger EC-coated area $(4 \pm 2 \%)$ was observed, but the difference was not statistically significant $(p>0.05)$. Cells were evenly distributed on the entire surface. Single SMCs with spherical morphology were 
observed (<1\%). On PU_YIGSR, ECs presented flattened morphology. There very unevenly distributed on the surface; there were gathered in dense clusters, but a cell-free area was also observed. For this surface EC-coated area was the biggest $(11 \pm 8 \%)$, the difference was also statistically significant compared to both PU and PU_REDV. The SMC-coated area was slightly higher compared to PU_REDV, but still very small $(<1 \%)$.

After $72 \mathrm{~h}$ of culture, on unmodified PU, an increase in EC-coated area was observed $(8 \pm 6 \%)$. However, only single SMCs were still visible during observation (SMC-coated area $<1 \%$ ). Both peptide-modified surfaces were densely coated with ECs. Also, an increase in cell-coated area was observed compared to the previous time point. There was no significant difference between both variants of peptide coating, and the ECs-coated area was $10 \pm 7 \%$ for PU_REDV and $12 \pm 3 \%$ for PU_YIGSR. A slight increase in the number of surface-adhered SMCs was observed. However, the area was still small $(<5 \%)$.

\subsection{Blood-Material Interaction}

\subsubsection{Platelet Adhesion and Activation under Static and Dynamic Conditions}

The hemocompatibility analysis was performed in a flow system. After a 1-h of contact between the prosthesis and the circulating blood, the internal surface of the prostheses was analyzed. No material leakage or soaking was observed. The percentage of area occupied by all platelets (anti-tubulin staining) and activated platelets (anti-CD62P staining) are presented in Table 3. Areas with local clusters of platelets or no platelets on each surface could be observed, resulting in high SD values. For all analyzed variants, the percentage of the area occupied by the platelets was below $5 \%$, with no statistically significant differences $(p>0.05)$. The percentage of the area covered with CD62P-positive platelets was reduced on peptide-modified surfaces compared to the unmodified PU. There were no significant differences between PU_REDV and PU_YIGSR $(p>0.05)$.

Table 3. Analysis of blood-material interaction in flow system.

\begin{tabular}{cccc}
\hline & PU & PU_REDV & PU_YGSR \\
\hline $\begin{array}{c}\text { \% of area covered with platelets } \\
\text { (anti-tubulin staining) }\end{array}$ & $3.2 \pm 2.7$ & $4.3 \pm 8.8$ & $3.8 \pm 5.2$ \\
\hline $\begin{array}{c}\text { \% of area covered with activated platelets } \\
\text { (CD62P staining) }\end{array}$ & $0.4 \pm 0.5$ & $0.1 \pm 0.1$ & $0.1 \pm 0.1$ \\
\hline
\end{tabular}

SEM images of materials and the percentage of the surface covered by adhered platelets for each surface variant are presented in Figure 9. Peptide modification significantly reduced the percentage of platelets area $(p<0.05)$, from $36.7 \pm 8 \%$ for PU to $8.5 \pm 6.5 \%$ and $3.7 \pm 2.4 \%$ for PU_REDV and PU_YIGSR, respectively. It proves the positive influence of the suggested peptide sequences on the adhesion of platelets. Platelets of different morphology can be found on all materials tested-round, dendritic platelets and spread dendritic morphology. On unmodified PU, platelet aggregates predominated, and the majority of them had spread dendritic morphology. In contrast, on PU_REDV and PU_YIGSR, platelets appeared singly and had round and dendritic morphology.

After static contact with blood, the percentage of surface area covered with platelets was low and below $5 \%$ for all tested materials (no significant difference $p>0.05$ ) (Figure 10). The adhered platelets showed varied morphology (i.e., round, dendritic, and spread), with no morphological type predominating over the others. 
$36.7 \pm 8.0 \%$
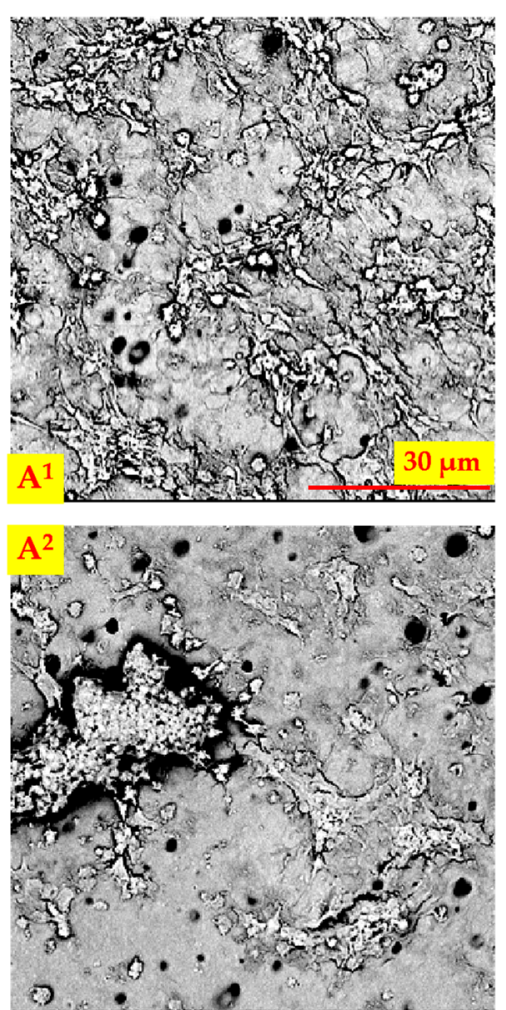

$8.5 \pm 6.5 \%$
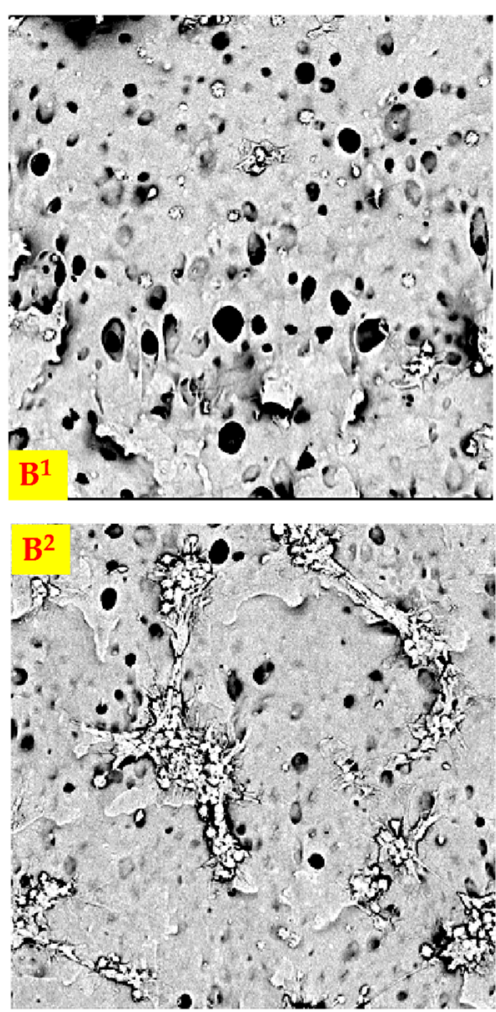

$3.7 \pm 2.4 \%$
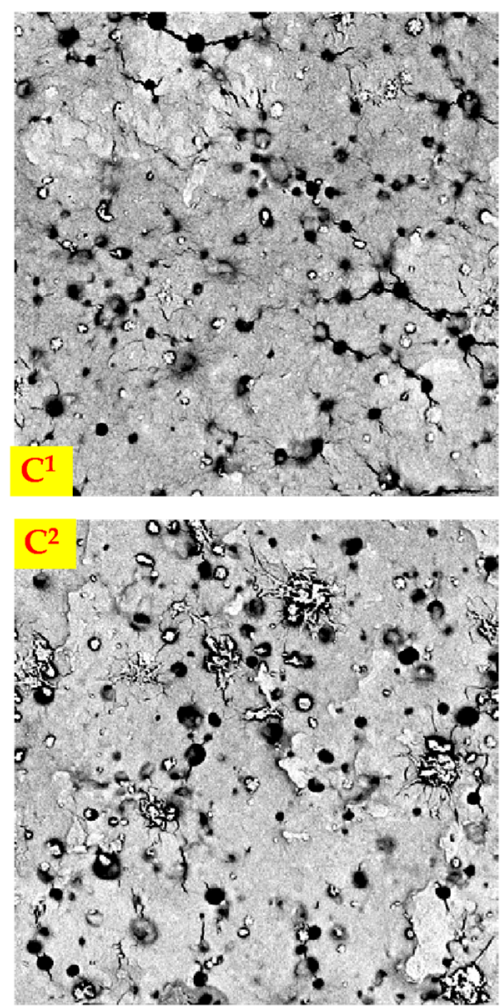

Figure 9. SEM images of analyzed materials' surface after contact with blood, $\left(\mathbf{A}^{\mathbf{1 , 2}}\right)$ : unmodified PU, $\left(\mathbf{B}^{\mathbf{1 , 2}}\right)$ : PU_REDV, $\left(\mathbf{C}^{\mathbf{1 , 2}}\right)$ : PU_YIGSR, scale bar $30 \mu \mathrm{m}$; the percentage of the platelet-coated area is given above each image.

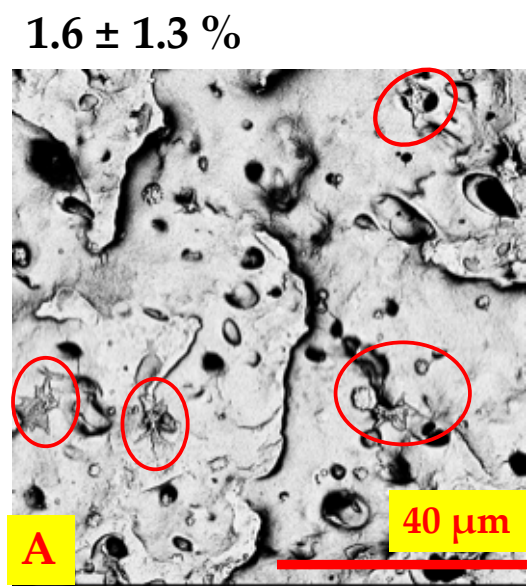

$1.9 \pm 1.0 \%$

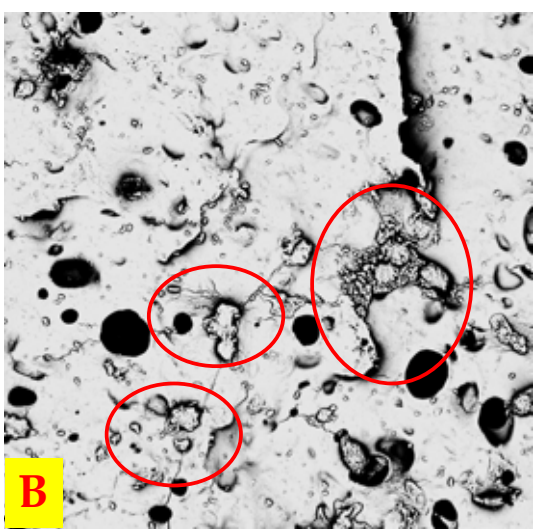

\section{$1.8 \pm 1.5 \%$}

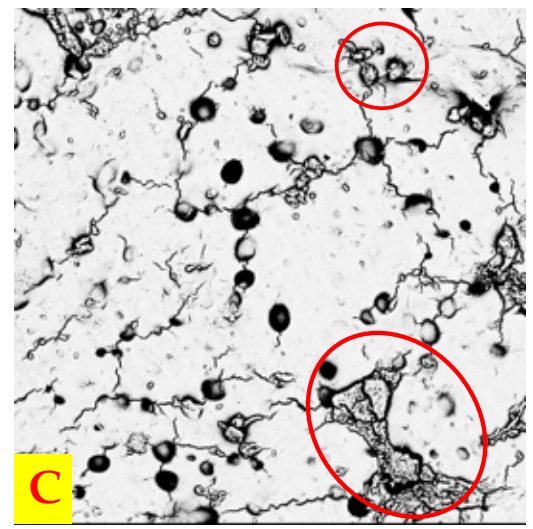

Figure 10. SEM images of analyzed materials' surface after contact with blood, (A) unmodified PU, (B) PU_REDV, ad (C) PU_YIGSR, scale bar $40 \mu \mathrm{m}$; the percentage of the platelet-coated area is given above each image.

\subsubsection{Whole Blood Clotting Time}

Figure 11 presents the change in the amount of hemoglobin released (absorbance measured at $540 \mathrm{~nm}$ ) from blood samples contacted with materials for 5, 10, 15, and $30 \mathrm{~min}$. The higher content of free hemoglobin corresponds to a lower amount of clot produced (which means higher hemocompatibility of the material contacted with blood sample). 


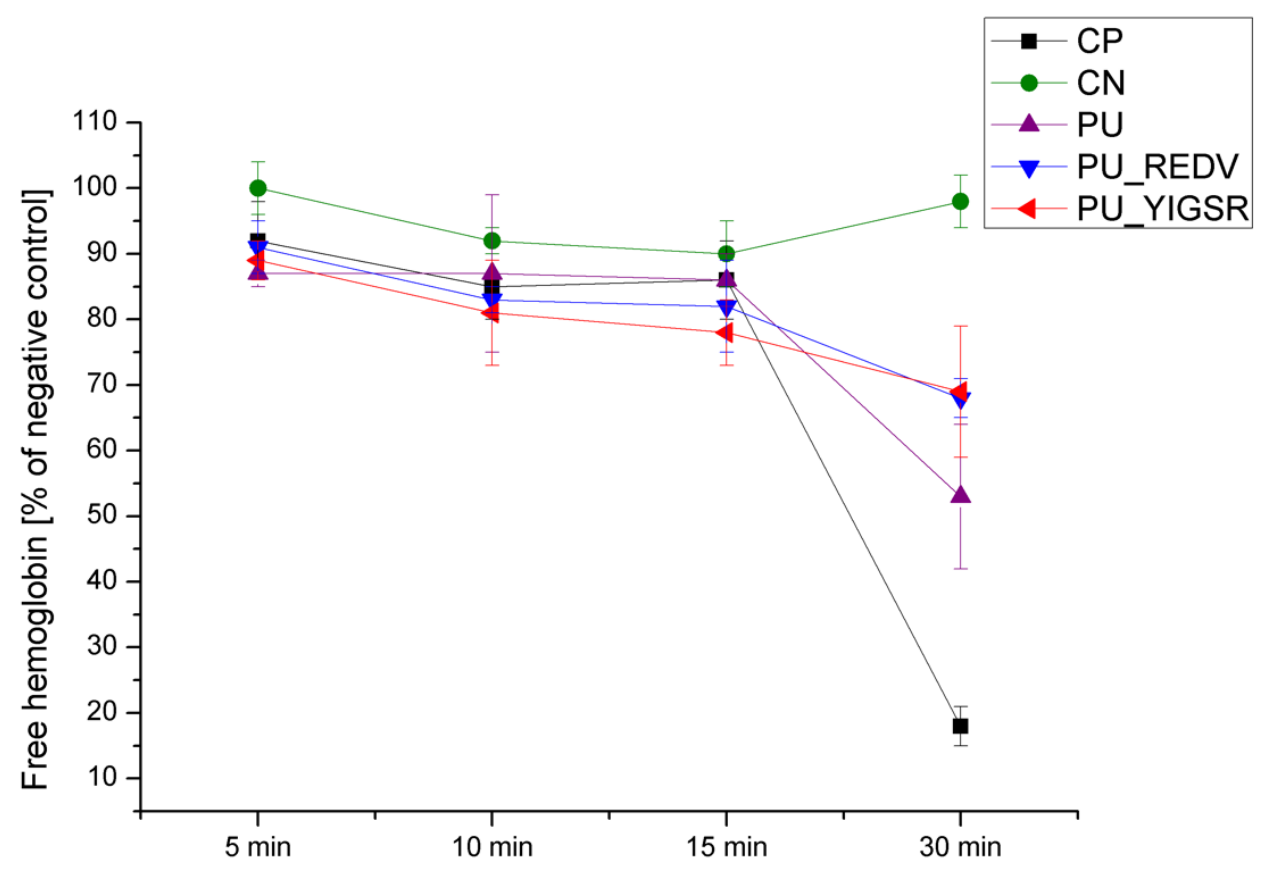

Figure 11. Results of whole blood clotting time assay.

The negative control (blood without $\mathrm{CaCl}_{2}$ ) did not clot at any time point tested and presented free hemoglobin values $\geq 90 \%$. In contrast, in the positive control (blood with the addition of $\mathrm{CaCl}_{2}$ ), a clot was formed after $30 \mathrm{~min}$, and the level of free hemoglobin dropped to $18 \pm 3 \%$. In the case of analyzed materials, there was no significant difference in the level of free hemoglobin in the first three time points ( $5 \mathrm{~min}, 10 \mathrm{~min}$, and $15 \mathrm{~min}$ ). After $30 \mathrm{~min}$ of contact, there were differences in the amount of free hemoglobin present in blood samples contacted with the materials. Blood contacted with pristine PU had free hemoglobin of $53 \pm 11 \%$. Blood contacted with the peptide-modified materials had a significantly $(p<0.05)$ higher free hemoglobin content: $68 \pm 3$ and $69 \pm 10 \%$, respectively, for PU_REDV and PU_YIGSR. There was no statistically significant $(p>0.05)$ difference between values for PU_REDV and PU_YIGSR at that time point.

\section{Discussion}

The following studies are a continuation of the works presented in our previous paper [31]. In that paper, parameters for the production of cylindrical structures by the phase inversion were selected. The following work presents the material modified with a peptide coating and analyzes the influence of the applied modification on the properties of the prostheses, with the main focus on its bio- and hemocompatibility.

Surface modification is an integral part of work on vascular prostheses. Bioactive molecules' introduction simultaneously changes surface hydrophilicity, which is reported to enhance cell adhesion [38]. Moreover, the use of appropriate peptides promotes the adhesion and growth of endothelial cells, naturally occurring in blood vessels. Therefore, in the research described here, it was decided to use the REDV and YIGSR peptide sequences. These are one of the most often studied EC-selective sequences [39]. A crucial aspect of the modification is also its effect on the blood-material interaction. Immediately after implantation of the material, the nonspecific adsorption of various proteins from serum and water occurs [40]. As the scaffold will be in constant and direct contact with blood, it cannot increase clotting or platelet adhesion. That is also the reason why changing the wettability of the surface is such an important issue [41].

Each step of the surface modification reaction was monitored by the FTIR and XPS. The analysis is consistent with the results obtained on materials obtained via different methods (solvent casting, solution blow spinning) with varying reaction parameters [31,42], 
confirming that the reaction occurred. This proves that it is possible to introduce acrylic acid and peptide sequences on material produced by the phase inversion technique. The reaction is also confirmed by a change in wettability. The grafting of carboxyl groups alone reduced the CA, and the introduction of peptide sequences further increased the surface hydrophilicity. This is a fully expected result [41,43]. Colorimetric analysis with TBO correspondingly confirmed the occurrence of the reaction. After reacting with the peptide sequences, the number of $\mathrm{COOH}$ groups on the surface decreased as they engaged in the reaction. The response of materials after modification with the peptide sequences is an expected result, as all peptides have carboxyl groups in their structures.

An increase in pore diameter of the internal surface was observed after the reaction with AA. With a different surface activation method, Seman et al. proved that AA grafting could increase the pore diameter [44]. Similarly, Shi et al. showed an increase in pore diameter after a reaction with AA [45]. The increase in pore diameter is most likely due to surface activation with cerium ions, a short reaction time, and low AA concentration. In the event of a longer time and higher AA concentration, the diameter of surface pores would likely decrease. However, such surface pores in small-diameter vascular prostheses, according to Camper et al. [46], should have higher patency rates and the development of thinner neointima. Moreover, the range of pore sizes shown by the obtained materials should favor the growth of EC [47]. The surface modification increased the porosity of the material without changing the surface morphology. This is a favorable phenomenon that should allow for better tissue overgrowth [48]. For the PU_AA, the porosity was higher than for the peptide materials (statistically insignificant difference). The reduction of porosity is related to the modification steps.

The YM increase is in line with previous research on fibrous material [42]. The increase in YM was observed after modification with the REDV peptide, similar to the studies described here. Compared to those studies, the tensile strength did not increase that much. On the other hand, elongation at the break here decreased. Those results prove how the mechanical properties depend on the very structure of the material. The modification slightly influenced the mechanical properties; however, the values of the analyzed parameters are within the ranges appropriate for vascular prostheses [49].

The use of the described modification did not affect the viability of L929 cells that were contacted with the material extracts. An EC and SMC co-culture was performed on unmodified and peptide-modified materials, where both cells' types were in close contact. As a result, it was possible to evaluate the competitive attachment and growth between endothelial and smooth muscle cells. Cells culture was carried out for three days due to the dyes used for the observation (imaging of live cells). On the first day, on the unmodified material, the ECs were not flattened, while on the peptide-modified materials, there were more of them, with flattened morphology. This proves the positive effect of the used peptides. On PU_REDV, ECs were found on the entire materials surface, while on PU_YIGSR, they were densely clustered, and the rest of the materials remained cell-free. Despite seeding both types of cells in the same number, the number of ECs cells was significantly higher than the number of SMCs. On the second day, the cells increased their number. Spherical and flattened cells were visible on the PU. On PU_REDV and PU_YIGSR, EC significantly increased their occupied area, showing that the introduced peptide positively affects their adhesion and growth promotion. Such an effect on EC was also observed on the third day on both peptide-modified materials. This is fully confirmed in the literature $[50,51]$. There is also an increase in the area occupied by the SMC, but it is a slower process than in the case of the EC. On the first day, SMC appeared singly on all materials. In the following days of cell culture, they began to adopt their typical elongated morphology. However, on each analyzed culture day and each type of material, the number of SMCs was significantly lower compared to the number of ECs.

In the case of blood-material tests, it was decided that we would perform an hour-long contact of the material with blood based on literature reports [52,53]. Tubulin is important for platelet mobilization, reshaping, and formation of pseudopod [54]. P-selectin (CD62P) 
is a marker of platelet activation. After activation, P-selectin moves to the platelet surface, and the P-selectin-specific antibody binds exclusively to the activated platelets [55]. Blood analyzes showed that both platelet adhesion and activation were low. Platelet adhesion and activation indicate the prevalent mechanism by which biomaterial thrombogenicity occurs [8]. Zhang and Shen demonstrated that increasing hydrophilicity favors platelet adhesion [56]. In addition, the introduction of peptides to the surface may increase platelet adhesion. Our research showed that both REDV and YIGSR peptides reduced the percentage of the area covered with adhered or activated (CD62P-positive) platelets. Thus, promoting effect of the introduced peptide on platelet adhesion was found, as confirmed by other authors $[9,12]$. It should be emphasized that in the studies, medical-grade polyurethane with low thrombogenicity was used, hence why there was such a low percentage of platelets on all tested materials. Morphology of the surface-adhered platelets was varied. However, platelet spread in large aggregates prevailed on unmodified PU, forms typical for activated platelets [55]. On the peptide-modified surfaces, round and single dendritic platelets dominated, characteristic for inactive plates. On the other hand, there are differences in the percentage of the area occupied by platelets and their morphology on the material's surface after dynamic and static flow. This is due to the nature of the contact. When the shear stress is removed, the blood behaves like an elastic solid. Therefore, in the case of static, the adhesion of platelets was most affected by the surface's wettability. Hence the similar blood platelet counts and their morphologies on all materials. As already mentioned, medical-grade polyurethane was used; therefore, no significant differences between analyzed samples in static contact could be expected. During dynamic contact, additional forces (shear stress) due to the flow acted on the blood that activated platelets. The flow system was more like the natural environment inside the blood vessels that favors the activation of platelets. This result proves the influence of peptide sequences on the behavior of platelets.

In order to assess the activation of the coagulation mechanism, the whole blood clotting time test was used. The test evaluates the level of free hemoglobin released from red blood cells that were not trapped in the clot formed during blood-material contact. The difference in the free hemoglobin level appeared after $30 \mathrm{~min}$ of incubation. Pristine PU had a significantly lower free hemoglobin level compared to the peptide-modified materials. This result confirmed the positive influence of the introduced coating on surface hemocompatibility, which is in line with the literature data [25].

In summary, the method of obtaining and modifying cylindrical polyurethane structures obtained via phase inversion was presented. These materials are designed for use as vascular prostheses. It has been shown that the introduced peptide coating increases the adhesion of EC cells while maintaining low adhesion of SMCs. The introduced peptides did not increase platelet adhesion and activation. At the same time, a positive effect on the amount of free hemoglobin present in the blood contacted with the analyzed surface was demonstrated.

\section{Materials and Methods}

\subsection{Materials}

Polyurethane, ChronoFlex C45D, was bought in the form of pellets from AdvanSource Biomaterial, Wilmington, MA, USA. N,N-dimethylacetamide (DMAC), acrylic acid (AA, 99\%), sodium dodecyl sulphate (SDS, 98\%), 1-ethyl-3-(3-dimethylaminopropyl) carbodiimide (EDC, purity $\geq 98.0 \%)$, MES buffer (2-(N- morpholino)ethanesulfonic acid, $\geq 99.5 \%$ ), phosphate-buffered saline (PBS, tablets), toluidine blue O (TBO), sodium hydroxide $(\mathrm{NaOH})$, acetic acid, hexamethyldisilazane (HMDS), ethanol(EtOH, 99\%) were purchased from Sigma Aldrich, Poznań, Poland. Nitric acid $\left(\mathrm{HNO}_{3}, 65 \%\right)$ was purchased from Carlo Erba, ammonium cerium (IV) sulphate dihydrate ((NH4)4Ce(SO4)4.2H2O, p.a. grade) from Riedel-de Haen). Peptides with GSGREDVGSG (REDV) and GSGYIGSRGSG (YIGSR) sequences (purity $\geq 98 \%$ ) were purchased from Novazym, Poznań, Poland (REDV, 
99.52\%). N-hydroxysulfosuccinimide (sulfo-NHS, purity $\geq 98.0 \%$ ) was purchased from ThermoFisher, Waltham, MA, USA.

\subsection{Materials Preparation}

\subsubsection{Preparation of Polyurethane Scaffolds}

The cylindrical scaffolds were obtained using the phase inversion method with ethanol as the non-solvent. This process was described in detail in our previous work [30]. Briefly, PU granules were first purified with $70 \% \mathrm{EtOH}$ solution and dried at $40{ }^{\circ} \mathrm{C}$. A $20 \% \mathrm{w} / \mathrm{v}$ PU/DMAC solution was prepared and mixed on a shaker until the polymer was completely dissolved. After that, the metal collector $(\varnothing 6 \mathrm{~mm})$ was immersed in a polymer solution. Subsequently, the collector coated with polyurethane solution was immersed in the nonsolvent $(0: 100$ water $/ \mathrm{EtOH})$ for $24 \mathrm{~h}$; the process was carried out at $50^{\circ} \mathrm{C}$. After this time, the scaffolds were removed from the collector and dried at room temperature (RT) with increased humidity.

\subsubsection{Surface Modification}

The obtained scaffolds were modified with acrylic acid, followed by conjugation with peptides. The samples subjected to the modification had the shape of cylinders with an internal diameter of $5 \mathrm{~mm}$ and a length of $40 \mathrm{~mm}$. Materials were placed individually in test tubes at each step of the reaction. Samples were fully immersed in a modifying solution with a volume of $5 \mathrm{~mL}$ (to have a constant ratio of surface area to the solution volume) and placed on a roller mixer for the reaction time (to provide a constant flow of modification solutions through the inner part of the materials). The modification reaction was performed in two steps. In the first step, samples were incubated in a $2.3 \%(v / v)$ solution of nitric acid in distilled water solution, to which was added $\left(\mathrm{NH}_{4}\right)_{4} \mathrm{Ce}\left(\mathrm{SO}_{4}\right)_{4}$ (final concentration $=0.01 \% w / v$ ) and AA (final concentration $=1 \% v / v$ ). The reaction was carried out for $30 \mathrm{~min}$ at RT. Then, the materials were rinsed with SDS solution $(0.1 \%$ w/v) and water for $20 \mathrm{~min}$. Materials after this modifications step were marked as PU_AA. In the second modification step, samples were incubated in an MES buffer $(0.05 \mathrm{M}, \mathrm{pH}=6.0)$ for $1 \mathrm{~h}$, RT. After that time, materials were transferred to the solution of sulfo-NHS ( $5 \mathrm{mM}$ ) and EDC ( $2 \mathrm{mM})$ in MES buffer, $\mathrm{pH}=6.0$, and incubated for $15 \mathrm{~min}$. Materials were rinsed with MES buffer and then incubated in the peptide solution (GSGREDVGSG or GSGYIGSRGSG, $20 \mu \mathrm{g} / \mathrm{mL}$ in PBS, $\mathrm{pH}=8$ ) for $1 \mathrm{~h}$, RT. Afterward, samples were rinsed with PBS, $\mathrm{pH}=8$, followed by rinsing with water. Materials after reaction with REDV or YIGSR peptides were marked as PU_REDV, PU_YIGSR, respectively.

\subsection{Physicochemical Properties}

\subsubsection{Surface Morphology}

Samples' morphology was analyzed using a scanning electron microscope (SEM, Phenom G1, Phenom World, Eindhoven, The Netherlands). Rectangular fragments were cut from each cylindrical structure $(n=4)$. The internal surfaces were examined, and images from randomly selected spots were captured. Surface pore sizes $(n=100)$ were measured with ImageJ based on SEM images [57].

\subsubsection{Chemical Characterization}

FTIR spectra were recorded with Nicolet 6700 Smart Orbit Diamond ATR (Thermo Scientific, Waltham, MA, USA) and analyzed with the use of the Omnic 8.3 software. The materials were cut open and tested to analyze the inner surface. Spectra were recorded in at least three randomly selected spots, and each material was prepared in triplicate.

X-ray photoelectron spectroscopy (XPS) analysis was conducted using Scienta R4000. Spectra fitting and determination of atomic composition were obtained with the CasaXPS software. 


\subsubsection{Wettability}

The wettability of the materials was analyzed after each step of modification using a DSA100 goniometer (Krüss $\mathrm{GmbH}$, Hamburg, Germany). Flat square fragments of cylindrical structures $(n=4)$ were cut off and glued to a glass slide. A droplet of distilled water $(5 \mu \mathrm{L})$ was placed on each material, and water contact angle (CA) was measured automatically with DSA100 goniometer's software.

\subsubsection{Carboxyl Groups Determination}

In order to calculate the surface density of $\mathrm{COOH}$ groups, a toluidine blue (TBO) assay was performed using a protocol described elsewhere [58]. Square fragments (sample size: $1 \mathrm{~cm} \times 1 \mathrm{~cm}, \mathrm{n}=4)$ were placed separately in a $500 \mu \mathrm{L}$ of TBO solution $(0.5 \mathrm{mM}, \mathrm{pH} 11)$ for $3 \mathrm{~h}$ at RT. After the incubation, samples were gently flushed with water, paper-dried, and placed in $500 \mu \mathrm{L}$ of $50 \%$ acetic acid solution $(50 \% v / v, \mathrm{pH} 1.5)$ for $15 \mathrm{~min}$, RT. After the incubation time, the absorbance of the solutions was measured at $633 \mathrm{~nm}$ using a plate reader. The surface density of $\mathrm{COOH}$ groups was calculated based on the standard curve.

\subsection{Porosity}

The porosity of the materials was determined by the gravimetric method $[59,60]$. Prosthesis (cylindrical) was cut into $20 \mathrm{~mm}$ in length and weighed $(\mathrm{n}=4)$. The porosity of materials was calculated based on its apparent density $\left(\rho_{\text {app }}\right)$ and known density of the polymer $\left(\rho_{\mathrm{p}}=1.2 \mathrm{~g} / \mathrm{cm}^{3}[61]\right)$, in accordance with the formula:

$$
\text { porosity }[\%]=\left(1-\rho_{\mathrm{app}} / \rho_{\mathrm{p}}\right) \times 100 \%
$$

where values of $\rho_{\text {app }}$ were measured from the weight and dimensions of the materials $(\mathrm{n}=4)$.

\subsection{Mechanical Testing}

Cylindrical samples (5 $\mathrm{mm}$ inner diameter, $60 \mathrm{~mm}$ length; $\mathrm{n}=4)$ were subjected to uniaxial tensile testing according to protocols based on ASTM standards (882-02 and D 638-02a). The study was performed using the Instron 3345 model with $5 \mathrm{~mm} / \mathrm{min}$ head speed at RT and ambient humidity.

\subsection{Cytotoxicity}

The cytotoxicity study, MTT assay (Thiazolyl Tetrazolium Blue Bromide, SigmaAldrich, Poznań, Poland), was performed according to ISO 10993-5 [62]. L929 cells were grown in Dulbecco Modified Eagle Medium (DMEM, ThermoFisher, Waltham, MA, USA) supplemented with bovine serum $(10 \% v / v$, ThermoFisher, Waltham, MA, USA) mixture of penicillin-streptomycin antibiotics ( $1 \% v / v$, ThermoFisher, Waltham, MA, USA) in an incubator $\left(37^{\circ} \mathrm{C}, 5 \% \mathrm{CO}_{2}\right)$.

Materials (cylindrical fragment) were sterilized with a solution of penicillin-streptomycin (100 U/mL, GibcoTM, ThermoFisher, Waltham, MA, USA) and 0.1\% $(v / v)$ amphotericin B (GibcoTM, ThermoFisher, Waltham, MA, USA) in sterile PBS at $4{ }^{\circ} \mathrm{C}$ for $1 \mathrm{~h}$. Next, samples were washed five times with sterile PBS on a plate shaker for $5 \mathrm{~min}$. Then, materials were incubated in DMEM for $24 \mathrm{~h}$ to obtain the material's extracts. Cells were seeded in a 96-well plate at a $1 \times 10^{5} / \mathrm{mL}$ density and cultured for $24 \mathrm{~h}$. Next, material extracts were added to the cells and incubated for $24 \mathrm{~h}$. Cells incubated with DMEM and cells incubated with $0.1 \%$ Triton $\mathrm{X}$ in DMEM were used as a negative and positive control, respectively. On the next day, a solution of MTT ( $1 \mathrm{mg} / \mathrm{mL}$ DMEM) was added to the wells. The plates were incubated for $4 \mathrm{~h}$. Then, the solution was removed, and formazan crystals were dissolved in isopropanol. Absorbance was measured at $\lambda 570 \mathrm{~nm}$.

Cell viability was calculated from following formula:

$$
\text { cell viability }[\%]=\mathrm{A}_{\mathrm{S}} / \mathrm{A}_{\mathrm{C}} \times 100 \%
$$


where: $A_{S}$ is the sample mean absorbance value, $A_{C}$ is the negative control mean absorbance value.

\subsection{Endothelial and Smooth Muscle Cell Co-Culture}

Human Umbilical Vein Endothelial Cells (EC, Lonza, Basel, Switzerland) were cultured in Endothelial Cell Growth Medium-2 (EGM-2, Lonza, Basel, Switzerland). Smooth Muscle cells (SMC, Lonza, Basel, Switzerland) were cultured in Smooth Muscle Cell Growth Medium 2 (PromoCell, Heidelberg, Germany); both media were supplemented according to the manufacturer's instructions. All cells were grown in an incubator at $37^{\circ} \mathrm{C}, 5 \% \mathrm{CO}_{2}$.

Materials (flat squares) were sterilized in a mixture of antibiotics as described in Section 4.6.

Before cell seeding, EC and SMC cells were stained in culture flasks with CellTracker ${ }^{\mathrm{TM}}$ Green (EC) and CellTracker ${ }^{\mathrm{TM}}$ Red (SMC) dyes (Invitrogen, Waltham, MA, USA) according to the manufacturer's instructions. Briefly, the medium was removed from the culture, $1.5 \mathrm{~mL}$ of dye solution was added to the flask and incubated for $30 \mathrm{~min}$ in an incubator. After removing the dye, cells were harvested using trypsin. Then cells were mixed in a 1:1 ratio and seeded on sterilized materials (total cell density $1.0 \times 10^{5} / \mathrm{mL}$ ). After culture, the microscope slides were prepared for observation under the confocal microscope.

\subsection{Interaction with Blood}

Whole blood was collected in $1.8 \mathrm{~mL}$ test tubes containing citrate (BD Vacutainer, Franklin Lakes, NJ, USA) from a healthy woman. The blood was brought from the Center for Blood Donation. Blood was immediately used in the experiments.

\subsubsection{Blood-Material Interaction}

For dynamic testing, the samples were cylinders with an internal diameter of $5 \mathrm{~mm}$ and a length of $40 \mathrm{~mm}$. Each sample was contacted with $5 \mathrm{~mL}$ of whole blood circulating in a flow system with a $20 \mathrm{~mL} / \mathrm{min}$ flow for $1 \mathrm{~h}$ as recommended by the other authors [52]. After this time, the materials were rinsed with $0.9 \% \mathrm{NaCl}$ and further analyzed. The materials were cut open and subjected to further analysis.

For tubulin staining materials were fixed in the CytoFix/CytoPerm Kit (BD Biosciences, Franklin Lakes, NJ, USA) for $20 \mathrm{~min}$ at $4{ }^{\circ} \mathrm{C}$. The samples were then washed with Wash Buffer and incubated in 0.1\% Bovine Serum Albumin (BSA)/PBS for $60 \mathrm{~min}$. Samples were washed in PBS, $3 \times 5 \mathrm{~min}$. After that, the materials were incubated with the alpha Tubulin Monoclonal Antibody eFluor 615 (eBioscience TM (Waltham, MA, USA), 1: 200 in PBS) in the dark at RT for $1 \mathrm{~h}$. After this time, the materials were washed in PBS, $3 \times 5 \mathrm{~min}$. The materials were glued to the cover glass with ProLong Gold antifade mountant (Thermo Fisher, Waltham, MA, USA) and left for analysis. For the CD62P staining, materials were incubated with the primary antibody, Recombinant Anti-CD62P (1: 500 in 1\% BSA/PBS), for $2 \mathrm{~h}$, RT. The samples were then washed very thoroughly with PBS, $3 \times 5 \mathrm{~min}$. Afterward, the materials were incubated with Goat Anti-Rabbit IgG H\&L secondary antibody (Alexa Fluor $^{\circledR}$ 488, Thermo Fisher, Waltham, MA, USA) (1: 1000 in 1\% BSA/PBS) for 1h, in the dark, RT. The materials were then rinsed with PBS, $3 \times 5$ min, glued to the cover glass with the ProLong Gold antifade mountant, and left for analysis. For SEM analysis, materials were fixed in 4\% PFA, rinsed with PBS, and dehydrated in an increasing EtOH series (50\%, $60 \%, 70 \%, 80 \%, 90 \%, 100 \%, 10 \mathrm{~min}$ each). The materials were then incubated with a 1:2 $\mathrm{EtOH} /$ hexamethyldisilazane (HMDS) mixture and left for $20 \mathrm{~min}$. After this time, the materials were transferred to a 2:1 EtOH/HMDS mixture. After $20 \mathrm{~min}$, the materials were flooded with HDMS solution and left for the next $20 \mathrm{~min}$. Finally, samples were left to dry overnight, coated with a $15 \mathrm{~nm}$ layer of gold/palladium alloy (80/20 at. \%), and subjected to SEM observation (SEM, Phenom G1, PhenomWorld, Eindhoven, The Netherlands). The percentage of the platelet-coated area was calculated using Fiji software. 
Samples were also contacted with blood under static conditions. Each material (flat square, $0.5 \mathrm{~cm} \times 0.5 \mathrm{~cm}$ size) was incubated with whole blood $(500 \mu \mathrm{L})$ at $37^{\circ} \mathrm{C}$ for $1 \mathrm{~h}$, followed by a procedure for SEM analysis described above.

\subsubsection{Whole Blood Clotting Time}

The antithrombogenicity of obtained materials was assessed using a whole blood kinetic clotting time method described elsewhere $[63,64]$. The cylindrical materials were cut open, and samples were prepared in the form of square pieces with dimensions of $5 \times 10 \mathrm{~mm}$. Three replicates were used for each time point. $1 \mathrm{~mL}$ of $0.1 \mathrm{M} \mathrm{CaCl}_{2}$ solution was added to freshly drawn blood $(10 \mathrm{~mL})$ to activate the blood coagulation mechanism. A well of a polystyrene plate with activated or inactivated (without $\mathrm{CaCl}_{2}$ ) blood was used as a positive $(\mathrm{CP})$ or negative control $(\mathrm{CN})$, respectively. The test was carried out in static conditions by placing $50 \mu \mathrm{L}$ of activated blood on each material. Incubation $(5,15,30 \mathrm{~min})$ was carried out at RT. After each time point, $1.5 \mathrm{~mL}$ of water was added to the material and incubated for the next $5 \mathrm{~min}$. Next, $200 \mu \mathrm{L}$ of the obtained solution was transferred to a 96-well plate, and absorbance was measured at $540 \mathrm{~nm}$.

The percentage of free hemoglobin was calculated from the following formula:

$$
\text { Free hemoglobin }[\%]=\mathrm{A}_{\mathrm{S}} / \mathrm{A}_{\mathrm{CN} 5} \times 100 \%
$$

where: $A_{S}$ is the sample mean absorbance value, $A_{C N 5}$ is the negative control mean absorbance value after 5 min of blood-material contact.

\subsection{Statistical Analysis}

The results were expressed as mean values \pm SD. Statistical significance of differences was investigated with a single-factor analysis of variance (ANOVA) for $p<0.05$ with post-hoc Tukey's test (OriginPRO 8.0, OriginLab Corporation, Northampton, MA, USA).

\section{Conclusions}

Cylindrical vascular scaffolds were prepared from polyurethane solution using a simple phase inversion technique. Next, acrylic acid conjugated with REDV/YIGSR peptide were successfully introduced to the prosthesis' surface. Peptide-modified internal surfaces have a pore size in the range of 1-11 $\mu \mathrm{m}$ with an average pore size of approximately $5 \mu \mathrm{m}$. The obtained prostheses had a porosity of about $60 \%$, Young's Modulus in the range of 9-11 MPa, and a water contact angle around $40^{\circ}$. MTT assay demonstrated that all analyzed materials were not cytotoxic. Peptide modification contributed to enhanced adhesion and proliferation of ECs on the internal surface. At the same time, the peptide-modified surfaces promoted adhesion of ECs over SMCs, as confirmed by the co-culture of both cell types. Analysis of blood-material interactions confirmed the high level of prostheses hemocompatibility. It has been shown that the applied peptide coating significantly reduced the amount of clot formed during blood-material contact. The study of platelet adhesion under flow conditions showed that the surface area occupied by the platelets on the REDV-coated prosthesis was 4 times smaller, and on the YIGSR-coated prosthesis, 10 times smaller compared to the prosthesis without peptide coating. Considering the above results, it can be concluded that the peptide coating increased the hemocompatibility of the surface by increasing ECs adhesion and, at the same time, decreasing platelet adhesion. Comparing both types of peptide coatings, more promising results were obtained for the surfaces coated with the YISGR than the REDV-coated prostheses.

Author Contributions: Conceptualization, A.K. and B.A.B.-R.; methodology, A.K. and B.A.B.-R.; validation, A.K.; investigation, A.K. and A.W.; formal analysis, A.K. and B.A.B.-R.; visualization, A.K. and B.A.B.-R.; writing- original draft preparation, A.K.; writing-review and editing, A.K. and B.A.B.-R.; supervision, A.K. and B.A.B.-R.; project administration, B.A.B.-R.; funding acquisition, B.A.B.-R. All authors have read and agreed to the published version of the manuscript. 
Funding: This work was supported by the National Centre for Research and Development in the frame of Project Contract No LIDER/18/0104/L-8/16/NCBR/2017.

Institutional Review Board Statement: Not applicable.

Informed Consent Statement: Not applicable.

Data Availability Statement: Not applicable.

Conflicts of Interest: The authors declare no conflict of interest.

\section{References}

1. Virani, S.S.; Alonso, A.; Benjamin, E.J.; Bittencourt, M.S.; Callaway, C.W.; Carson, A.P.; Chamberlain, A.M.; Chang, A.R.; Cheng, S.; Delling, F.N.; et al. Heart disease and stroke statistics-2020 update: A report from the American Heart Association. Circulation 2020, 141, E139-E596. [PubMed]

2. Parikh, V.; Kadiwala, J.; Hidalgo Bastida, A.; Holt, C.; Sanami, M.; Miraftab, M.; Shakur, R.; Azzawi, M. Small diameter helical vascular scaffolds support endothelial cell survival. Nanomed. Nanotechnol. Biol. Med. 2018, 14, 2598-2608. [CrossRef] [PubMed]

3. Boffito, M.; Sartori, S.; Ciardelli, G. Polymeric scaffolds for cardiac tissue engineering: Requirements and fabrication technologies. Polym. Int. 2014, 63, 2-11. [CrossRef]

4. Yu, K.; Mei, Y.; Hadjesfandiari, N.; Kizhakkedathu, J.N. Engineering Biomaterials Surfaces to Modulate the Host Response. Colloids Surf. B Biointerfaces 2014. Available online: http:/ / www.ncbi.nlm.nih.gov/pubmed/25193153 (accessed on 10 August 2021).

5. Ren, X.; Feng, Y.; Guo, J.; Wang, H.; Li, Q.; Yang, J.; Hao, X.; Lv, J.; Ma, N.; Li, W. Surface modification and endothelialization of biomaterials as potential scaffolds for vascular tissue engineering applications. Chem. Soc. Rev. 2015, 44, 5680-5742. [CrossRef]

6. Zhuang, Y.; Zhang, C.; Cheng, M.; Huang, J.; Liu, Q.; Yuan, G.; Lin, K.; Yu, H. Challenges and strategies for in situ endothelialization and long-term lumen patency of vascular grafts. Bioact. Mater. 2021, 6, 1791-1809. [CrossRef]

7. Patterson, J.; Martino, M.M.; Hubbell, J.A. Biomimetic materials in tissue engineering. Mater. Today 2010, 13, 14-22. [CrossRef]

8. Adipurnama, I.; Yang, M.C.; Ciach, T.; Butruk-Raszeja, B. Surface modification and endothelialization of polyurethane for vascular tissue engineering applications: A review. Biomater. Sci. 2017, 5, 22-37. [CrossRef]

9. Qi, P.; Maitz, M.F.; Huang, N. Surface modification of cardiovascular materials and implants. Surf. Coat. Technol. 2013, 233, 80-90. [CrossRef]

10. Wu, J.; Hu, C.; Tang, Z.; Yu, Q.; Liu, X.; Chen, H. Tissue-engineered Vascular Grafts: Balance of the Four Major Requirements. Colloids Interface Sci. Commun. 2018, 23, 34-44. [CrossRef]

11. Clauser, J.; Gester, K.; Steinseifer, U.; Sonntag, S.J. Regulating Blood Cell Adhesion via Surface Modification of Polyurethanes; Elsevier Ltd.: Amsterdam, The Netherlands, 2016; pp. 287-318.

12. Jana, S. Endothelialization of cardiovascular devices. Acta Biomater. 2019, 99, 53-71. [CrossRef]

13. Navas-Gómez, K.; Valero, M.F. Why polyurethanes have been used in the manufacture and design of cardiovascular devices: A systematic review. Materials 2020, 13, 3250. [CrossRef]

14. Ward, R.S.; Jones, R.L. Polyurethanes and Silicone Polyurethane Copolymers. Vol. 1, Comprehensive Biomaterials II; Elsevier Inc.: Amsterdam, The Netherlands, 2017; pp. 570-619.

15. Knetsch, M.L.W.; Koole, L.H. VEGF-E enhances endothelialization and inhibits thrombus formation on polymeric surfaces. J. Biomed. Mater. Res.-Part A 2010, 93, 77-85. [CrossRef]

16. Shin, H.; Jo, S.; Mikos, A.G. Biomimetic materials for tissue engineering. Biomaterials 2003, 24, 4353-4364. Available online: http:/ / www.ncbi.nlm.nih.gov/pubmed/12922148 (accessed on 8 August 2021). [CrossRef]

17. Gupta, B.; Plummer, C.; Bisson, I.; Frey, P.; Hilborn, J. Plasma-induced graft polymerization of acrylic acid onto poly(ethylene terephthalate) films: Characterization and human smooth muscle cell growth on grafted films. Biomaterials 2002, 23, 863-871. [CrossRef]

18. Lopez, L.C.; Gristina, R.; Ceccone, G.; Rossi, F.; Favia, P.; d’Agostino, R. Immobilization of RGD peptides on stable plasmadeposited acrylic acid coatings for biomedical devices. Surf. Coat. Technol. 2005, 200, 1000-1004. [CrossRef]

19. Davoudi, P.; Assadpour, S.; Derakhshan, M.A.; Ai, J.; Solouk, A.; Ghanbari, H. Biomimetic modification of polyurethane-based nanofibrous vascular grafts: A promising approach towards stable endothelial lining. Mater. Sci. Eng. C 2017, 80, 213-221. [CrossRef] [PubMed]

20. Zhao, J.; Bai, L.; Ren, X.K.; Guo, J.; Xia, S.; Zhang, W.; Feng, Y. Co-immobilization of ACH11 antithrombotic peptide and CAG cell-adhesive peptide onto vascular grafts for improved hemocompatibility and endothelialization. Acta Biomater. 2019, 97, 344-359. [CrossRef] [PubMed]

21. Cai, L.; Heilshorn, S.C. Designing ECM-mimetic materials using protein engineering. Acta Biomater. 2014, 10, 1751-1760. [CrossRef] [PubMed]

22. Devalliere, J.; Chen, Y.; Dooley, K.; Yarmush, M.L.; Uygun, B.E. Improving functional re-endothelialization of acellular liver scaffold using REDV cell-binding domain. Acta Biomater. 2018, 78, 151-164. [CrossRef] 
23. Kanie, K.; Narita, Y.; Zhao, Y.; Kuwabara, F.; Satake, M.; Honda, S.; Kaneko, H.; Yoshioka, T.; Okochi, M.; Honda, H.; et al. Collagen type IV-specific tripeptides for selective adhesion of endothelial and smooth muscle cells. Biotechnol. Bioeng. 2012, 109, 1808-1816. Available online: http://www.ncbi.nlm.nih.gov/pubmed/22359201 (accessed on 5 August 2021). [CrossRef]

24. Munisso, M.C.; Yamaoka, T. Novel peptides for small-caliber graft functionalization selected by a phage display of endothelialpositive/platelet-negative combined selection. J. Mater. Chem. B 2013, 5, 9354-9364. [CrossRef] [PubMed]

25. Peng, G.; Yao, D.; Niu, Y.; Liu, H.; Fan, Y. Surface Modification of Multiple Bioactive Peptides to Improve Endothelialization of Vascular Grafts. Macromol. Biosci. 2019, 19, 1800368. [CrossRef] [PubMed]

26. Castellanos, M.I.; Zenses, A.S.; Grau, A.; Rodríguez-Cabello, J.C.; Gil, F.J.; Manero, J.M.; Pegueroles, M. Biofunctionalization of REDV elastin-like recombinamers improves endothelialization on $\mathrm{CoCr}$ alloy surfaces for cardiovascular applications. Colloids Surf. B Biointerfaces 2015, 127, 22-32. [CrossRef] [PubMed]

27. Adhikari, K.R.; Tucker, B.S.; Thomas, V. Tissue Engineering of Small-Diameter Vascular Grafts [Internet]. Vol. 1957, Biointegration of Medical Implant Materials; Elsevier Ltd.: Amsterdam, The Netherlands, 2019; pp. 79-100.

28. Natasha, G.; Tan, A.; Gundogan, B.; Farhatnia, Y.; Nayyer, L.; Mahdibeiraghdar, S.; Rajadas, J.; De Coppi, P.; Davies, A.H.; Seifalian, A.M. Tissue engineering vascular grafts a fortiori: Looking back and going forward. Expert Opin. Biol. Ther. 2015, 15, 231-244.

29. Kucinska-Lipka, J.; Gubanska, I.; Janik, H.; Sienkiewicz, M. Fabrication of polyurethane and polyurethane based composite fibres by the electrospinning technique for soft tissue engineering of cardiovascular system. Mater. Sci. Eng. C 2015, 46, 166-176. [CrossRef]

30. Kuźmińska, A.; Kwarta, D.; Ciach, T.; Butruk-Raszeja, B.A. Cylindrical Polyurethane Scaffold Fabricated Using the Phase Inversion Method: Influence of Process Parameters on Scaffolds' Morphology and Mechanical Properties. Materials 2021, $14,2977$. [CrossRef]

31. Butruk-Raszeja, B.A.; Kuźmińska, A.; Ciach, T.; Adipurnama, I.; Yang, M.C. Endothelial cell growth on polyurethane modified with acrylic acid and REDV peptide. Surf. Innov. 2020, 8, 89-104. [CrossRef]

32. Butruk-Raszeja, B.A.; Dresler, M.S.; Kuźmińska, A.; Ciach, T. Endothelialization of polyurethanes: Surface silanization and immobilization of REDV peptide. Colloids Surf. B Biointerfaces 2016, 144, 335-343. [CrossRef] [PubMed]

33. Asefnejad, A.; Khorasani, M.T.; Behnamghader, A.; Farsadzadeh, B.; Bonakdar, S. Manufacturing of biodegradable polyurethane scaffolds based on polycaprolactone using a phase separation method: Physical properties and in vitro assay. Int. J. Nanomed. 2011, 6, 2375-2384. [CrossRef]

34. Auguścik, M.; Kurańska, M.; Prociak, A.; Karalus, W.; Lipert, K.; Ryszkowska, J. Production and characterization of poly(ureaurethane) elastomers synthetized from rapeseed oil-based polyols Part I. Structure and properties. Polimery 2016, 61, 490-498. [CrossRef]

35. Qu, X.H.; Wu, Q.; Liang, J.; Qu, X.; Wang, S.G.; Chen, G.Q. Enhanced vascular-related cellular affinity on surface modified copolyesters of 3-hydroxybutyrate and 3-hydroxyhexanoate (PHBHHx). Biomaterials 2005, 26, 6991-7001. [CrossRef] [PubMed]

36. Moulder, J.; Stickle, W.; Sobol, P.; Bomben, K. Handbook of X-ray Photoelectron Spectroscopy; PerkinElmer, Inc.: Waltham, MA, USA, 1992.

37. Gardner, S.D.; Singamsetty, C.S.K.; Booth, G.L.; He, G.R.; Pittman, C.U. Surface characterization of carbon fibers using angleresolved XPS and ISS. Carbon N. Y. 1995, 33, 587-595. [CrossRef]

38. Tzoneva, R.; Faucheux, N.; Groth, T. Wettability of substrata controls cell-substrate and cell-cell adhesions. Biochim. Biophys. Acta-Gen. Subj. 2007, 1770, 1538-1547. [CrossRef] [PubMed]

39. Enemchukwu, N.O.; García, A.J. Peptide- and Protein-Modified Surfaces. In Comprehensive Biomaterials II; Elsevier Inc.: Amsterdam, The Netherlands, 2017; pp. 200-220.

40. Ratner, B.D.; Bryant, S.J. Biomaterials: Where we have been and where we are going. Annu. Rev. Biomed. Eng. 2004, 6, 41-75. [CrossRef]

41. Bai, L.; Zhao, J.; Li, Q.; Guo, J.; Ren, X.; Xia, S.; Zhang, W.; Feng, Y. Biofunctionalized Electrospun PCL-PIBMD/SF Vascular Grafts with PEG and Cell-Adhesive Peptides for Endothelialization. Macromol. Biosci. 2019, 19, 1800386. [CrossRef]

42. Butruk-Raszeja, B.A.; Kuźmińska, A.; Wojasiński, M.; Piotrowska, Z. Physicochemical and Mechanical Properties of Blow Spun Nanofibrous Prostheses Modified with Acrylic Acid and REDV Peptide. Coatings 2020, 10, 1110. [CrossRef]

43. Choi, W.S.; Joung, Y.K.; Lee, Y.; Bae, J.W.; Park, H.K.; Park, Y.H.; Park, J.C.; Park, K.D. Enhanced Patency and Endothelialization of Small-Caliber Vascular Grafts Fabricated by Coimmobilization of Heparin and Cell-Adhesive Peptides. ACS Appl. Mater. Interfaces 2016, 8, 4336-4346. [CrossRef]

44. Seman, M.N.A.; Khayet, M.; Hilal, N. Comparison of two different UV-grafted nanofiltration membranes prepared for reduction of humic acid fouling using acrylic acid and N-vinylpyrrolidone. Desalination 2012, 287, 19-29. [CrossRef]

45. Shi, S.; Zhou, Y.; Lu, X.; Ye, Y.; Huang, J.; Wang, X. Plasma-initiated DT graft polymerization of acrylic acid on surface of porous polypropylene membrane for pore size control. Plasma Chem. Plasma Process. 2014, 34, 1257-1269. [CrossRef]

46. Contreras, M.A.; Quist, W.C.; LoGerfo, F.W. Effect of porosity on small-diameter vascular graft healing. Microsurgery 2000, 20, 15-21. [CrossRef]

47. Yalcin Enis, I.; Gok Sadikoglu, T. Design parameters for electrospun biodegradable vascular grafts. J. Ind. Text. 2018, 47, 2205-2227. [CrossRef] 
48. Ji, Y.; Wei, Y.; Liu, X.; Wang, J.; Ren, K.; Ji, J.; Van Wachem, P.B.; Hogt, A.H.; Beugeling, T.; Bantjes, A.; et al. Tissue engineered vascular grafts-Preclinical aspects. Biomaterials 2011, 30, 38-47. [CrossRef]

49. Zhou, F.; Wen, M.; Zhou, P.; Zhao, Y.; Jia, X.; Fan, Y.; Yuan, X. Electrospun membranes of PELCL/PCL-REDV loading with miRNA-126 for enhancement of vascular endothelial cell adhesion and proliferation. Mater. Sci. Eng. C 2018, 85, 37-46. [CrossRef]

50. Ji, Y.; Wei, Y.; Liu, X.; Wang, J.; Ren, K.; Ji, J. Zwitterionic polycarboxybetaine coating functionalized with REDV peptide to improve selectivity for endothelial cells. J. Biomed. Mater. Res. A 2012, 100, 1387-1397. Available online: http:/ /www.ncbi.nlm. nih.gov/pubmed/22374807 (accessed on 10 August 2021). [CrossRef] [PubMed]

51. Wei, Y.; Ji, Y.; Xiao, L.L.; Lin, Q.K.; Xu, J.P.; Ren, K.F.; Ji, J. Surface engineering of cardiovascular stent with endothelial cell selectivity for in vivo re-endothelialisation. Biomaterials 2013, 34, 2588-2599. Available online: http://www.ncbi.nlm.nih.gov/ pubmed/23352039 (accessed on 5 August 2021). [CrossRef] [PubMed]

52. Blok, S.L.J.; van Oeveren, W.; Engels, G.E. The optimal incubation time for in vitro hemocompatibility testing: Assessment using polymer reference materials under pulsatile flow with physiological wall shear stress conditions. J. Biomed. Mater. Res.-Part B Appl. Biomater. 2019, 107, 2335-2342. [CrossRef] [PubMed]

53. Zhang, Y.; Li, X.S.; Guex, A.G.; Liu, S.S.; Müller, E.; Malini, R.I.; Zhao, H.J.; Rottmar, M.; Maniura-Weber, K.; Rossi, R.M.; et al. Corrigendum: A compliant and biomimetic three-layered vascular graft for small blood vessels. Biofabrication 2017, 9, 029501. [CrossRef]

54. Cuenca-Zamora, E.J.; Ferrer-Marín, F.; Rivera, J.; Teruel-Montoya, R. Tubulin in Platelets: When the Shape Matters. Int. J. Mol. Sci. 2019, 20, 3484. [CrossRef]

55. Kannan, M.; Ahmad, F.; Saxena, R. Platelet activation markers in evaluation of thrombotic risk factors in various clinical settings. Blood Rev. 2019, 37, 100583. [CrossRef]

56. Zhang, E.; Shen, F. Blood compatibility of a ferulic acid (FA)-eluting PHBHHx system for biodegradable magnesium stent application. Mater. Sci. Eng. C 2015, 52, 37-45. [CrossRef]

57. Schindelin, J.; Arganda-Carreras, I.; Frise, E.; Kaynig, V.; Longair, M.; Pietzsch, T.; Preibisch, S.; Rueden, C.; Saalfeld, S.; Schmid, B.; et al. Fiji: An open-source platform for biological-image analysis. Nat. Methods 2012, 9, 676-682. [CrossRef] [PubMed]

58. Chollet, C.; Chanseau, C.; Brouillaud, B.; Durrieu, M.C. RGD peptides grafting onto poly(ethylene terephthalate) with well controlled densities. Biomol. Eng. 2007, 24, 477-482. Available online: https://www.sciencedirect.com/science/article/pii/S138 9034407000810 (accessed on 10 August 2021). [CrossRef] [PubMed]

59. Ahmed, M.; Ghanbari, H.; Cousins, B.G.; Hamilton, G.; Seifalian, A.M. Small calibre polyhedral oligomeric silsesquioxane nanocomposite cardiovascular grafts: Influence of porosity on the structure, haemocompatibility and mechanical properties. Acta Biomater. 2011, 7, 3857-3867. [CrossRef]

60. Yadav, P.; Beniwal, G.; Saxena, K.K. A review on pore and porosity in tissue engineering. In Materials Today: Proceedings; Elsevier Inc.: Amsterdam, The Netherlands, 2021.

61. Shtilman, M.I. Polymeric Biomaterials. Part I. Polymer Implants; CRC Press: Boca Raton, FL, USA, 2003.

62. ISO. Biological Evaluation of Medical Devices BS EN ISO 10993-12:2004; European Committee for Standardization: Brussels, Belgium, 2004; pp. 1-17.

63. Imai, Y.; Nose, Y. A new method for evalution of antithrombogenicity of materials. J. Biomed. Mater. Res. 1972, 6, 165-172. [CrossRef] [PubMed]

64. Motlagh, D.; Yang, J.; Lui, K.Y.; Webb, A.R.; Ameer, G.A. Hemocompatibility evaluation of poly(glycerol-sebacate) in vitro for vascular tissue engineering. Biomaterials 2006, 27, 4315-4324. [CrossRef] [PubMed] 